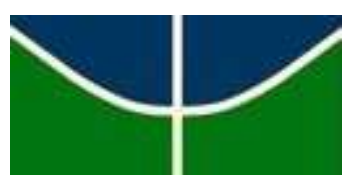

Universidade de Brasília - UNB

Instituto de Ciências Humanas - IH

Departamento de Geografia - GEA

RICARDO FIDELES DOS SANTOS

O ACESSO A MORADIA POR FAMÍLIAS DE BAIXA RENDA SEM

RESPALDO DAS POLÍTICAS DE HABITAÇÃO DO GOVERNO

DO DISTRITO FEDERAL: UMA ABORDAGEM DO

NÚCLEO HABITACIONAL SOL NASCENTE

BRASILIA-DF 
RICARDO FIDELES DOS SANTOS

\section{O ACESSO A MORADIA POR FAMÍLIAS DE BAIXA RENDA SEM RESPALDO DAS POLÍTICAS DE HABITAÇÃO DO GOVERNO \\ DO DISTRITO FEDERAL: UMA ABORDAGEM DO NÚCLEO HABITACIONAL SOL NASCENTE}

Trabalho apresentado ao curso de graduação em Geografia da Universidade de Brasília, como requisito para obtenção do título de Bacharel em Geografia.

Orientadora: Prof ${ }^{a}$. Drª . Marília Luíza Peluso

\section{BRASILIA-DF}


S237a SANTOS, Ricardo Fideles dos.

O acesso a moradia por famílias de baixa renda sem respaldo das políticas de habitação do governo do Distrito Federal: uma abordagem do Núcleo Habitacional Sol Nascente / Ricardo Fideles dos Santos. - Brasília: UnB, 2010.

$74 \mathrm{f}$.

Monografia (graduação em Geografia) - Universidade de Brasília, Departamento de Geografia, Brasília, 2010.

Orientadora: Prof ${ }^{a}$. Drª . Marília Luíza Peluzo.

1.Habitação irregular. 2. Políticas públicas. 3. Baixa renda. 4. Distrito Federal. I. Título. II. Santos. Ricardo Fideles. 


\section{O ACESSO A MORADIA POR FAMÍLIAS DE BAIXA RENDA SEM RESPALDO DAS POLÍTICAS DE HABITAÇÃO DO GOVERNO DO DISTRITO FEDERAL: UMA ABORDAGEM DO NÚCLEO HABITACIONAL SOL NASCENTE}

Monografia apresentada junto ao curso de graduação em Geografia da Universidade de Brasília, como requisito parcial para obtenção do título de Bacharel em Geografia.

Aprovada por:

Prof $^{\mathrm{a}}$. Dr ${ }^{\mathrm{a}}$ Marília Luíza Peluso- Orientadora Universidade de Brasília-UnB/ Departamento de Geografia-GEA

Prof. Dr. Dante Flávio da Costa Reis Júnior - Membro Universidade de Brasília-UnB/ Departamento de Geografia-GEA

Prof. MSc. Juvair Fernandes de Freitas - Membro Universidade de Brasília-Unb/ Departamento de Geografia-GEA 
"In memoriam"

A todos aqueles que deram mais do que suas lágrimas e suor para construir esta magnífica cidade, deram, acima de tudo, seu sangue e suas vidas não podendo assim assistir ao alvorecer de uma nova Capital. 
Agradeço,

a Deus por se fazer presente em todos os momentos da minha vida.

a minha Familia, Pai, mãe, esposa, irmãs, sobrinhos e sobrinhas e ao amigos que estão a meu lado em todos os momentos.

a Professora Marilia Peluso por dedicar parte de seu tempo para lêe comentar cada capítulo, aos colegas de serviço, que por muitas vezes assumiram minha função, permitindo assim que eu estivesse presente na faculdade.

A todos vocês um grande obrigado! 
Brasilia tem gente de tudo que é jeito, Brasilia tem gente de todo lugar, tudo aqui é muito longe e por mais que eu ande, Sem gasolina não vai dá pra chegar. Tem um clima bem dificil de levar, Em Julho faz mais frio do que você imagina A cidade é verde de Outubro pra frente não tem cor quando Maio termina. (Brasília. Condição de Existência. 1999. cd independente) 


\section{RESUMO}

A transferência da Capital para a região Central do país, como promessa de integração e desenvolvimento regional, atraiu para a área uma grande quantidade de imigrantes que buscavam a esperança de dias melhores, esse fator faz com que a previsão de 500.000 habitantes para 40 anos após a inauguração seja desconsiderada.

A cada dia mais e mais pessoas buscavam moradia, o governo respondeu a essa demanda criando cidades-satélites longe do Plano Piloto e sem infraestrutura, expulsando do centro as famílias de baixa renda.

Passado um longo período sem oferta de moradia para a população de baixa renda a taxa de déficit habitacional eleva-se extraordinariamente. Os governantes interessados em votos passam a distribuir lotes em períodos próximos a eleições, criando assim grandes redutos eleitorais. Nem mesmo essa prática é capaz de diminuir a demanda por moradia, já que muitas famílias deixavam de ser contempladas, pois a política habitacional do voto não respeitava critérios prédefinidos.

O governo local controlava e definia como se dava o acesso a terra na cidade, porém muitas pessoas percebendo uma demanda que existia começaram a parcelar terras particulares e públicas ilegalmente objetivando ganhos econômicos.

Esse processo de compra de terra irregular atingiu todas as camadas sociais da população da cidade. Os habitantes de baixa renda viram assim uma possibilidade de adquirirem o lote que tanto desejavam. É a partir daí que surge o setor habitacional Sol nascente na cidade de Ceilândia, servindo para abrigar a população de baixa renda que viviam sobre o regime de coabitação na cidade de Brasília ou entorno

Palavras chaves: Segregação sócio/espacial, Déficit habitacional, Parcelamentos irregulares, Baixa renda. 
ABSTRACT

The transfer of the Capital of Brazil to the central region of this country, as a promise of integration and regional development, has attract to this area a big quantity of immigrants, who comes hopping better days. This factor did the forecast of 500.000 of habitants to 40 years, after its opening, inconsiderable.

Each day more people look for a home. The government answered to this demand creating satellites-cities far from the center - Pilot Plan. These areas have no infrastructure. So, poor people were expelled from the center.

It has passed a long period without some offer of residences to population. The housing deficit has risen extraordinarily. The governing interested in votes start to distribute lands in periods which are next to the elections. So, it creates big "electoral redoubts". However, this practice was not able to reduce the demand for residences. It happened because many families were not benefited and the housing politics of vote does not respect pre-defined criterion.

The local government controlled and defined how will be the process of land access in the city, however, many people realized that this demand exists and they started to divide private and public lands illegally with the objective of economical gains.

This process of buying irregular lands affected all social areas of city's population. The habitants of low income realized this as a manner or possibility to obtain the house which they wished. From this process, the housing sector "Sol Nascente" appears located in the satellite-city called Ceilândia. It serves to abrogate the low income population who lived on a cohabitation regime in the city of Brasília, or around.

Keywords: Socio/spatial segregation, Housing Deficit, Irregular splitting, Low income. 


\section{LISTA DE ILUSTRAÇÕES}

Gráfico 1 - Naturalidade da População segundo as Grandes Regiões, Distrito Federal e Exterior - DF- 2007

Gráfico 2 - Classes de Renda Domiciliar Mensal, por agrupamento de Regiões Administrativas - 2004 26

Gráfico 3 - Domicílios por Classes de Renda - Distrito Federal - 2004 ................... 27 Imagem 1 - Poligonal da área ocupada pelo setor no ano de 2008 em vermelho

Imagem 2 - Representação parcial do mapa ambiental do DF de 2006 ............ 48

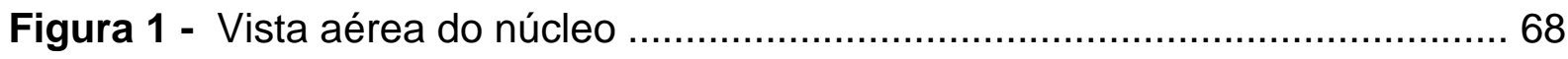

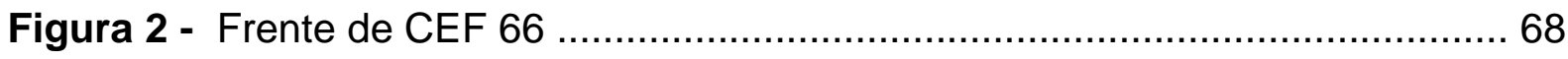

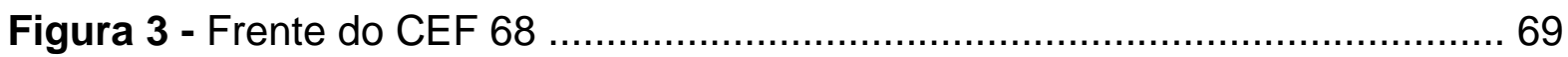

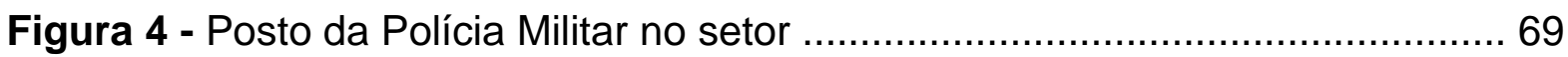

Figura 5 - Visão aérea do setor - instalação da Caesb ..................................... 70

Figura 6 - Avenida principal - instalação da Ceb …………………………..... 70

Figura 7- Final da avenida principal - ponto de alagamento ................................ 71

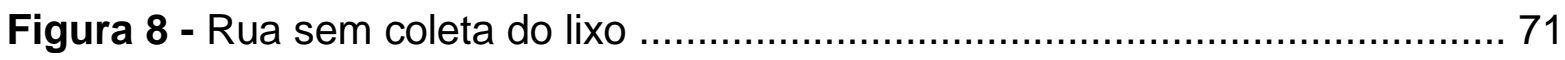

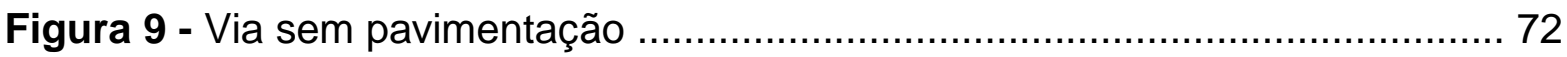

Figura 10 - Obra da Vila Olímpica .............................................................. 72

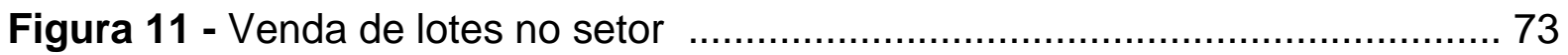

Figura 12 - Mapa parcial de regularização …………..................................... 74

\section{LISTA DE TABELAS}

Tabela 1 - Evolução da população do DF e Densidade Demográfica 19572007

Tabela 2 - Distrito Federal por grupos de Regiões Administrativas segundo as faixas de renda per capita mensal -2004

Tabela 3 - Distribuição do déficit habitacional na área urbana do DF por faixa de renda média familiar mensal ..................................................................... 37

Tabela 4 - Domicílios vagos em condições de serem ocupados e em construção na

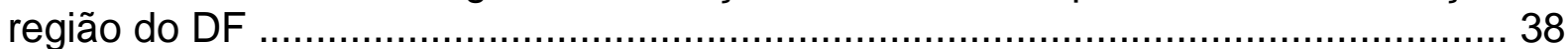

Tabela 5 - Ocupações irregulares no DF .................................................. 42 


\section{LISTA DE SIGLAS}

CODEPLAN - Companhia de desenvolvimento do Planalto

PDAD - Pesquisa distrital por amostra de domicílio

PNAD - Pesquisa nacional por amostra de domicílio

IBGE - Instituto brasileiro de Geografia e Estatística

FJP - Fundação João Pinheiro

BNH - Banco nacional de habitação

FGTS - Fundo de garantia por tempo de serviço

SEDUH - Secretaria de desenvolvimento urbano e habitação

NHPSN - Núcleo Habitacional Parque Sol Nascente (NHPSN)

SHSN - Setor Habitacional Sol Nascente

CEF - Centro de ensino fundamental

CAESB - Companhia de água e esgoto de Brasília

CEB- -Companhia energética de Brasília

PDOT - Plano diretor de ordenamento territorial

ARIS - Área de relevante interesse social 


\section{SUMÁRIO}

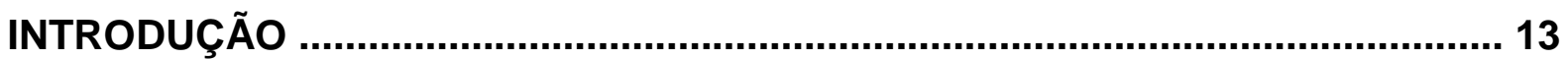

OBJETIVOS

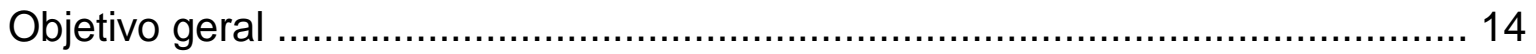

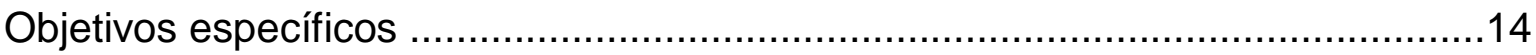

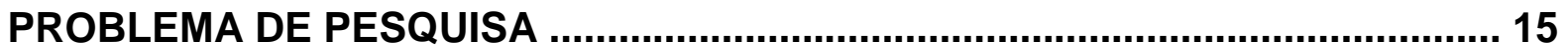

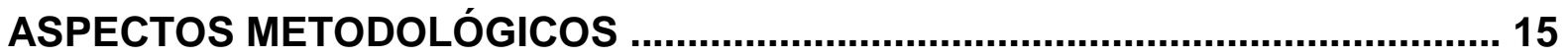

CAPÍTULO 1 - FORMAÇÃO POPULACIONAL E DISTRIBUIÇÃO RENDA .......... 17

1.1 Formação populacional: os migrantes construtores e seus filhos ................. 17

1.2 Perfis de renda da população do DF: uma distribuição econômica das regiões administrativas ................................................................................... 23

CAPÍTULO 2 - GESTÃO URBANA E DÉFICIT HABITACIONAL ........................ 28

2.1 Moradias para as famílias de baixa renda: cidades-satélites e

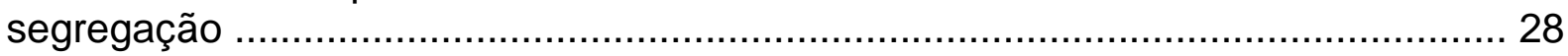

2.2 As políticas de habitação do DF: uma recorrente prática clientelista ............ 31

2.3 Déficit habitacional: um problema social que marca o DF .......................... 34

CAPÍTULO 3 - PROCESSO DE OCUPAÇÕES IRREGULARES …....................... 39

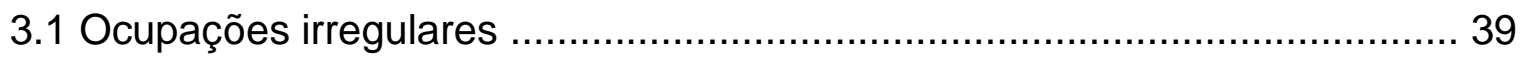

3.2 Núcleo habitacional parque sol nascente: parcelamento irregular de famílias de baixa renda .......................................................................................... 44

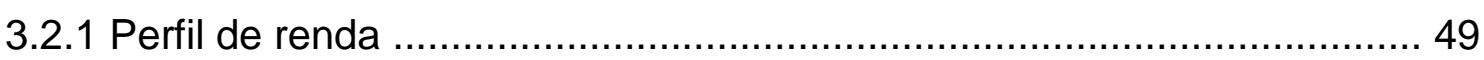

3.2.2 Conhecendo o sol nascente: infra-estrutura e equipamentos públicos 49

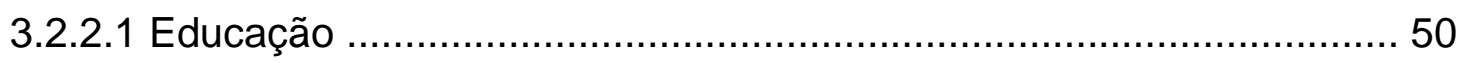

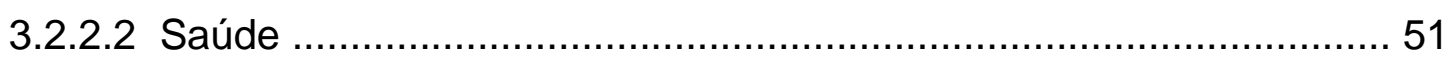

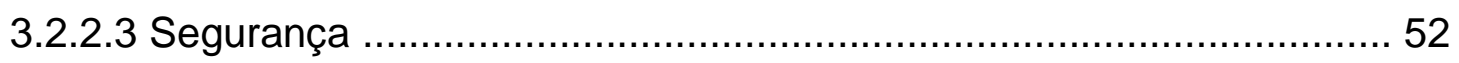

3.2.2.4 Água - luz - esgoto - coleta de lixo …………............................. 52

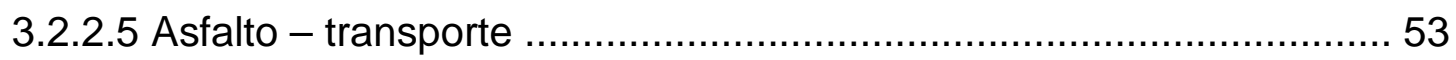

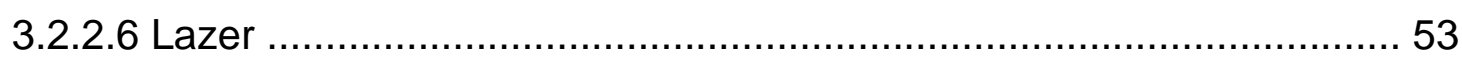

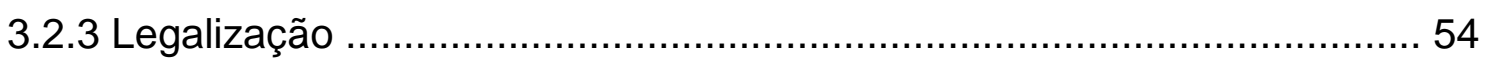

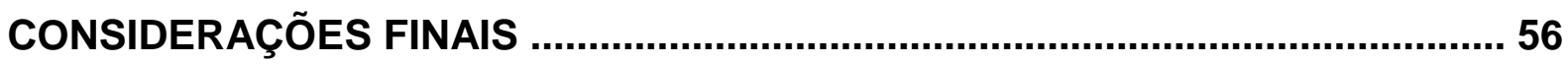

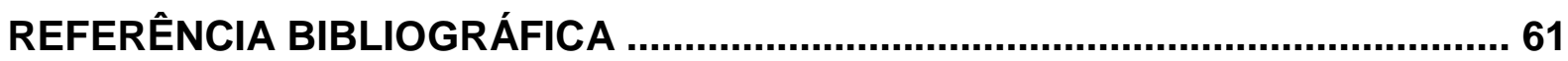

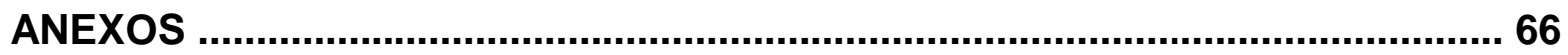




\section{INTRODUÇÃO}

O problema habitacional no Distrito Federal surge concomitante a transferência da capital para o centro do país. Os trabalhadores que para cá vieram em busca de melhores condições de vida se deparam com exaustivas jornadas de trabalho e moradia de baixa qualidade. As invasões e vilas irregulares cresciam ao redor dos canteiros de obras do que seria a futura capital. A solução adotada foi à transferência dos trabalhadores para as cidades-satélites recém criadas.

Apesar de previstas no plano original de Brasília tais cidades não recebem a infra-estrutura adequada no ato de sua instituição, fazendo de algumas delas depósitos de trabalhadores de baixa renda que não tinha onde residir. A proposta habitacional do governo da época não define critérios concretos para o assentamento desses trabalhadores e suas famílias, utilizando apenas a distância existente entre as cidades-satélites e o Plano-Piloto.

O déficit habitacional que surge a época não se apresenta devido a falta de áreas favoráveis a criação das cidades-satélites. O que se têm, é uma falta de política habitacional voltada para as famílias de baixa renda que trabalham na construção de Brasília.

O passar dos anos e o grande fluxo migratório rumo à nova capital faz surgir uma grande demanda habitacional, gerando assim um adensamento populacional nas cidades. As políticas habitacionais adotadas pelos governos parecem incapazes de oferecer uma solução adequada para o problema, as invasões se proliferam por todas as regiões de Brasília, novas políticas são adotadas, porém, por não utilizarem critérios claros, o problema habitacional persiste.

O anseio por moradia faz com que muitas pessoas busquem formas alternativas para conseguirem a tão sonhada casa. Surge então em Brasília um mercado informal de parcelamento de terras particulares e públicas, rurais ou em áreas de preservação, para atender a demanda das mais variadas classes de renda.

É nesse contexto que surge o Núcleo Habitacional Sol Nascente, localizado na cidade de Ceilândia, e que passará a atender a demanda de muitas famílias de baixa renda que há tempos buscavam um local para se estabelecerem, livre do aluguel na maioria dos casos, e ainda em busca da tão sonhada "Capital da Esperança". 


\section{OBJETIVOS}

\section{OBJETIVO GERAL}

Demonstrar que devido a forma como se desenvolveu a política habitacional no DF muitas famílias de baixa renda que não eram contempladas nas contínuas distribuições de moradias passaram a adquirir lotes em parcelamentos irregulares, sem o aval do governo, buscando assim suprir sua carência por moradia.

\section{OBJETIVOS ESPECÍFICOS}

- Demonstrar como se constitui o déficit habitacional das famílias de baixa renda de Brasília.

- Apontar de que forma as políticas de habitação tem atendido as famílias de baixa renda.

- Especificar que uma parcela das famílias de baixa renda deixa de ser atendida pelas políticas de habitação.

- Apresentar uma área de habitação irregular ocupada por famílias de baixa renda. 


\section{PROBLEMA DE PESQUISA}

Foi interessado em entender o motivo de muitas famílias de baixa renda não conseguirem conquistar uma moradia que me propus a fazer este trabalho sempre com o seguinte questionamento na cabeça.

Por que mesmo pertencendo à classe definida como de baixa renda, muitas famílias não têm acesso ao programa habitacional do governo destinado a elas?

\section{ASPECTOS METODOLÓGICOS}

O trabalho foi desenvolvido a partir de uma revisão bibliográfica - leitura e analises de trabalhos referentes ao tema e áreas afim - com objetivo de esclarecer os conceitos a serem abordados.

Foi feito um levantamento quantitativo de dados junto a órgãos do governo, e outros trabalhos de pesquisa, referente à migração, habitação e renda para demonstrar como se encontra o universo estudado.

A área de estudo foi definida após analise de como se distribui a renda da população dos moradores de Brasília.

Foram realizadas visitas a área de estudo para reconhecimento do local e coleta de dados e informação sobre o setor e seus moradores.

Foi feita uma entrevista com um grupo de moradores do local para definir-lhes o perfil, entender o motivo que os levaram a escolher a área em questão para moradia e identificar as necessidades deles referente á localidade.

Foi realizada uma pesquisa qualitativa através de entrevista com um grupo de moradores do Sol Nascente. As entrevistas transcorreram em dois dias, sendo realizada com um grupo inicial de quinze pessoas, que no momento da entrevista respondia como responsável pela casa, porém depois sendo reduzida á apenas dez válidas, pois cinco mostraram problemas técnicos.

Os entrevistados foram identificados no trabalho apenas pelo nome e número da chácara em que moram, foram omitidos sobrenomes, conjuntos e casas de forma a preservá-los. 
O presente trabalho se desenvolve em 3 capítulos e uma conclusão: $O$ primeiro capítulo dividido em dois subtemas aborda a fase inicial da construção de Brasília e o processo de migração para a cidade que deu origem a população, e também a forma como se distribuí a renda pelas várias regiões administrativas do DF.

O segundo capítulo trata da gestão urbana e do déficit habitacional, dividido em três subtemas sendo eles: o processo que deu origem as cidades-satélites, levado a efeito de forma a segregar a população de baixa renda da capital; as políticas de habitação do Distrito Federal e a forma clientelista como ocorreram e finalizando o capitulo, o déficit habitacional e a forma como se constituí no DF.

O terceiro capítulo aborda a forma como ocorreram as ocupações irregulares de terra no Distrito Federal, está estruturado em dois subtemas. O primeiro trata das ocupações irregulares e seu processo de formação em Brasília. O segundo aborda uma área específica que foi ocupada irregularmente dando origem ao Setor Habitacional Sol Nascente, destinado a famílias de baixa renda que buscavam uma moradia, descrevo o processo de formação do setor, faço uma breve especificação de como se encontra a infra-estrutura do local e finalizo o capítulo falando sobre a legalização da área. 


\section{CAPITULO 1 - FORMAÇÃO POPULACIONAL E DISTRIBUIÇÃO DE RENDA}

Um dos fatores principais para se explicar a dinâmica habitacional do Distrito Federal é o estudo da formação de sua população, Originária de grandes fluxos migratórios nas primeiras décadas de sua construção, ocorrendo uma retração posterior, porém, sendo ainda hoje de grande relevância na formação populacional da cidade, pois, mesmo após meio século de existência, uma grande parte da demanda habitacional de Brasília se deve a tais fluxos.

Outra corrente da demanda habitacional está relacionada ao próprio crescimento vegetativo da cidade, os "filhos de Brasília", muitos dos que aqui nasceram também enfrentam grande dificuldade em adquirir uma moradia, já que o mercado imobiliário mantém os valores elevados como forma de auferir um lucro cada vez maior.

Uma característica comum às duas categorias, os migrantes e os nascidos na cidade, na dificuldade de acesso à moradia, está relacionada à renda, pois, os que possuem uma baixa renda enfrentam grande dificuldade de acesso a crédito financeiro, dependendo, assim, exclusivamente de uma política habitacional específica, sendo que essa se mostra cada vez mais incapaz de atender à demanda .

\subsection{Formação populacional: Os migrantes construtores e seus filhos}

O Processo migratório para a capital do país decorre de algumas formas bem distintas. Em um primeiro momento, tem-se aquele original onde a função primária é a construção da cidade, projeto fruto de uma política de desenvolvimento do país que buscava integrar e desenvolver as regiões, pois o sistema produtivo nacional e o povoamento estavam muito centrados no litoral brasileiro. Como nos diz Paviani (2008, p.23), "com Brasília, desloca-se a fronteira do povoamento litorâneo para o interior". Dentro desse processo de integração, tinha-se a transferência da capital como fator determinante em vários aspectos: políticos, sociais, econômicos e também geoestratégicos.

Em outro momento ocorre a migração desenvolvida após a inauguração de Brasília, pois, mesmo tendo sido inaugurada a cidade ainda demandava grande 
quantidade de mão-de-obra, pois, grande parte dos equipamentos públicos e privados encontravam-se ainda em processo de construção ou a construir, e muitos órgãos públicos transferiam sua sede para a capital, necessitando, assim, de um alto número de funcionários que viriam de fora.

Esse fator mantém a corrente migratória elevada até meados da década de 1970. No inicio da década de 1980, já se percebe uma redução mais acentuada nos índices de migração do DF. Os fluxos migratórios começam a se modificar, pois, antes, o fator determinante deles era a busca por emprego. Tal fator ainda é preponderante no que se refere aos fluxos mais atuais, porém, outros fatores já servem como atrativos para os migrantes, entre eles temos o sistema de infraestrutura, educação e saúde, entre outros.

Ocorre ainda um intenso processo de migração pendular, oriunda da impossibilidade de muitas famílias que, em um primeiro momento, se deslocam para a capital, mas que ficam impossibilitadas de fixarem moradia na cidade, estabelecendo-se então nas regiões limítrofes da capital, conhecidas como entorno.

Esse ímpeto por mudança e o grande empenho desses que para cá vieram possibilitou a implantação da capital em uma região ainda pouco explorada. Se da forma que JK disse que cumpriria a constituição transferindo a capital para a região central do país, o que realmente fez, os sucessivos governos que o seguiram também se empenhassem em cumpri-la nos demais artigos, muitas outras mudanças poderiam ocorrer.

E como nos contam, assim nasceu Brasília;

- O senhor mudará a capital do país para o Planalto Central, como está previsto nas Disposições Transitórias da Constituição?

Toniquinho

- Acabo de prometer que cumprirei, na íntegra, a Constituição e não vejo razão para que esse dispositivo seja ignorado. Se for eleito, construirei a nova capital e farei a mudança da sede do governo.

Juscelino Kubitschek. (Discurso de Juscelino em Jataí. 4 de Abril de 1955,disponível em http://web.brasiliapoetica.blog.br)

O diálogo é emblemático, ficando marcado como a pedra fundamental da construção da nova capital, projeto levado a efeito pelo então eleito presidente JK. Dentro do projeto de desenvolver o Brasil, através de seu programa de metas " 50 anos em 5" Juscelino elege a construção da nova capital como carro chefe de seu governo. Por tal motivo, acreditava que Brasília deveria ser símbolo de um futuro grandioso que previa para o Brasil, como expõe em suas palavras, 
Quando convoquei Niemeyer para a construção de Brasília, disse-lhe o seguinte: "Você terá toda a liberdade para construir Brasília, mas quero que tenha uma coisa sempre em vista: é meu objetivo que, daqui a 100 anos, os pósteres, diante da cidade que vamos construir, digam: "Os que levantaram Brasília, há 100 anos passados, tiveram uma grande visão desta cidade e do futuro do Brasil, porque a construíram à altura de uma nação que eles sabiam viria a ser uma das mais poderosas do mundo. (OLIVEIRA, 19--? “Assim nasceu Brasília”. Disponível em: http://web.brasiliapoetica.blog.br)

Projeto tão ambicioso, construir uma capital no interior do país, necessitaria de uma grande massa de trabalhadores, a questão é: de onde viriam estes trabalhadores? Pois a área onde se realizaria o projeto não dispunha de tal contingente. É dessa forma que surge a figura daquele que foi 0 ator mais importante na construção de Brasília, o migrante, que, de acordo com Carvalho (2008, p. 13), "é aquele que deixa seu local de origem em busca de um sonho, impulsionado pelos seus desejos, um ser desejante." Brasília seria para estes migrantes esse sonho a ser buscado, o desejo a ser realizado, a personificação de todos os anseios que possuíam, ou, como dito por Maulraux" " A capital da esperança".

Para Souza (apud AMBROGI, 20--?, p.6), a migração interna é um processo social resultante de mudanças estruturais de um determinado país, que provoca o deslocamento horizontal de pessoas de todas as classes sociais que, por razões diversas, deixam o seu local de nascimento e vão fixar residência em outra área. Esse processo é bem característico em Brasília, onde se tem um grande fluxo de trabalhadores de diferentes níveis sociais e culturais, isso pode ser visto na forma como Holston identifica os trabalhadores que vieram para a cidade,

Holston identifica os trabalhadores que vieram construir a capital por quatro
denominações: Pioneiro, identificado como trabalhador de média e alta
qualificação, incluindo ainda os comerciantes e agricultores. Os Candagos,
constituídos principalmente pelos operários de baixa qualificação
profissional sendo a maioria de pouca escolaridade ou mesmo analfabetos.
Os Pioritários, autodenominação de alguns pioneiros por terem sidos
preteridos pela oficialidade após a inauguração de Brasília. E os
Brasilienses, termo substitutivo a candangos. (Holston apud Luiz, 2007, p
44), O governo utiliza todos os meios disponíveis para atrair os trabalhadores, disseminando a idéia de dias melhores e vida digna a todos aqueles que estivessem dispostos a embarcar nessa empreitada, como nos demonstra Gouvêa,

As pessoas migravam devido à intensa propaganda existente na época, que estimulava a vinda de brasileiros para construir a nova capital. Os

1 André Malraux, ministro dos assuntos culturais da França em discurso proferido em 24 de agosto de 1959 durante visita que fez as obras de construção da cidade 
candangos vinham para o Planalto Central não somente para construir uma cidade, mas para construir a 'capital da esperança', pois tinham a esperança de melhores dias para trazer suas famílias e viver com dignidade. (Gouvêa, 1991, p.81)

A propaganda governamental é tão eficiente que, em pouco tempo, o canteiro de obras da construção da capital torna-se o grande destino de inúmeras correntes migratórias, "[...] a propaganda oficial sobre oportunidades crescentes, descritas como verdadeiro "eldorado", facilitaram o recrutamento de mão-de-obra, por vezes, ociosa, em outras regiões." (PAVIANI 2007, p.16), correntes estas que antes tinham como direcionamento as metrópoles da época, Rio de Janeiro e São Paulo, de acordo com Vasconcelos (2006). Deixando claro o que Ambrogi (20--?, p.9) coloca "[...] o poder público sempre teve papel importante nos processos de migração através da criação de fatores de atração ou expulsão proporcionando a formação de espaços urbanos[...]".

Esse processo de migração com destino definido está dentro do que Santos e Silveira (apud AMBROGI, 20--?, p.8) chamam de "migrações internas axiais", e corresponderiam a um eixo de migração no sentido Nordeste-Centro-Sul, provocado pelo processo de industrialização de algumas metrópoles (São Paulo, Rio de Janeiro, Espírito Santo) e também pela chamada "marcha para o oeste", como nos conta Juscelino em um de seus discursos;

Coube a Brasília uma tarefa bem mais profunda e de muito maior alcance: a de puxar para o Oeste a massa a povoar o Brasil igualmente e, através desse empuxo migratório interno, realizar, quando muito no período de duas décadas, a verdadeira integração nacional. (OLIVEIRA, 19--?. "A Visão de Juscelino Kubitschek". Disponível em: http://www.gdf.df.gov.br/045/04501021.asp)

transformando Brasília em pólo de atração e aglutinação de populações, de acordo com Ambrogi (20--?), devido a grande demanda por força de trabalho.

Ao se tornar uma área de atração de correntes migratórias Brasília passa por um grande adensamento populacional, possuindo taxas de crescimento superiores à média nacional.

Um indicativo desse grande fluxo era que em 1959, portanto, um ano antes da inauguração, já havia aproximadamente 60.000 habitantes na cidade em construção, sendo ainda que $43 \%$ desses migrantes seriam oriundos da região Nordeste, é o que nos diz Luiz (2007). Para Ribeiro (apud LUIZ 2007), um dos motivos desse grande fluxo de migrantes nordestinos seria a grande seca que se abateu naquela região no ano de 1958. Nos anos de 1960/1970, a taxa de crescimento da cidade 
era de $14,4 \%$ e, nas décadas de $1970 / 1980$, de $8,2 \%$, onde, de acordo com o censo de 1970, 76\% da população residente em Brasília era de migrantes (Vasconcelos, et al. 2006). A tabela integrante do relatório da Companhia de desenvolvimento do Planalto (CODEPLAN) - Síntese de informações socioeconômicas do DF $(2008)^{2}$ demonstra essa evolução populacional.

\section{Tabela 1}

\section{Evolução da população do DF e Densidade Demográfica 1957-2007}

\begin{tabular}{|c|c|c|}
\hline Anos & População & $\mathrm{Hab} / \mathrm{Km}^{2}$ \\
\hline 1957 & 12.283 & 2,12 \\
\hline 1959 & 64.314 & 11,11 \\
\hline 1960 & 140.164 & 24,21 \\
\hline 1970 & 537.492 & 92,84 \\
\hline 1980 & 1.176 .935 & 203,30 \\
\hline 1991 & 1.601 .094 & 276,57 \\
\hline 1996 & 1.821 .946 & 314,72 \\
\hline 2000 & 2.051 .146 & 354,31 \\
\hline 2005 & 2.337 .076 & 403,71 \\
\hline 2006 & 2.392 .718 & 413,32 \\
\hline 2007 & 2.443 .574 & 422,10 \\
\hline Do & 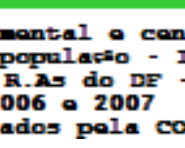 & $\begin{array}{l}\text { Sfico-IBes } \\
\text { ODEFLAS }\end{array}$ \\
\hline
\end{tabular}

FONTE: Relatório CODEPLAN (2008)

Nada parecia capaz de impedir a jornada da massa de trabalhadores que se deslocava para Brasília. Eles estavam dispostos a enfrentar as longas jornadas na boléia de caminhões, o conhecido "pau de arara", meio de transporte mais disponível na época da construção, na busca de uma vida mais digna.

Após as décadas iniciais de construção da capital, onde, como já foi dito, houve um grande fluxo de correntes migratórias, ocorreu uma redução nas taxas de migrantes em Brasília, fator relacionado em grande parte a dificuldade de acesso moradia na capital e ao surgimento de outros pólos de atração de mão de

2 O "Distrito Federal Síntese de Informações Socioeconômicas 2008" pretende atualizar o estudo elaborado pela CODEPLAN em 2006 e 2007, disponível no site www.codeplan.df.gov.br com a finalidade de proporcionar aos estudantes e à comunidade uma melhor compreensão do Distrito Federal. Contém informações, de acordo com a realidade atual, sobre o território, a população e suas interações socioeconômicas. O estudo é apresentado em cinco capítulos: Caracterização do Território; Caracterização Político - Administrativa; Caracterização da População; da Economia; e, da Região Integrada de Desenvolvimento do Distrito Federal e Entorno - RIDE. Síntese de Informações Socioeconômicas 2008. p.11. 
obra. A migração ainda se mostra como um fator bastante significativo na composição demográfica da cidade.

Isso pode ser comprovado pelo resultado da pesquisa distrital por amostra de domicílios (PDAD) 2004 onde 52\% da população residente no Distrito Federal declaram ter outra naturalidade, sendo de origem majoritária dos estados do Nordeste, com 26,7\%, seguidos pelo Sudeste, Centro-Oeste, Norte e região Sul, $13,7 \%, 7,8 \%, 2,1 \%, 1,4 \%$, respectivamente; e também pelos dados da CODEPLAN que em 2008 realizou análise da pesquisa nacional por amostra de domicílio (PNAD) do Instituto Brasileiro de Geografia e Estatística (IBGE) (PNAD/IBGE/2007), onde relata que $51,4 \%$ da população do Distrito Federal é originária de imigrantes, o gráfico 1 demonstra essa evolução.

\section{Gráfico 1}

\section{Naturalidade da População segundo as Grandes Regiões,} Distrito Federal e Exterior - DF- 2007

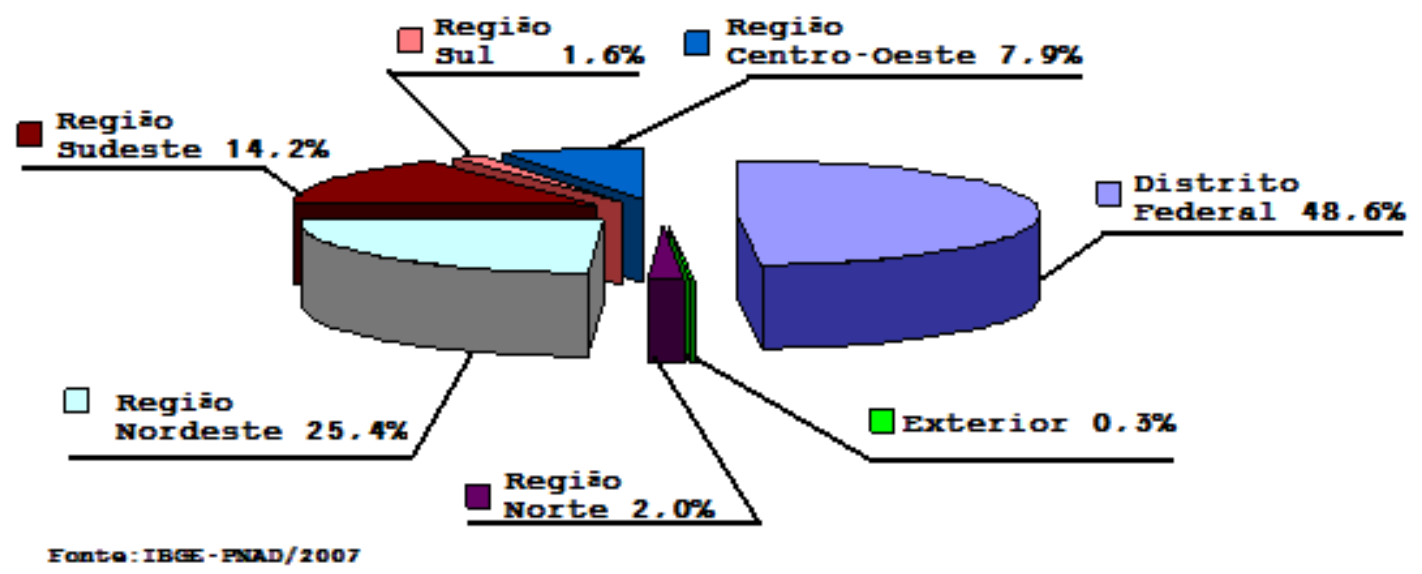

Fonte: Relatório CODEPLAN (2008)

O relatório sobre indicadores sociodemográficos prospectivo para o Distrito Federal 1991-2030/CODEPLAN(2009) traz ainda uma mudança de perfil das pessoas que migram mais recentemente para o DF.

As pessoas que migraram para o Distrito Federal em épocas mais recentes mostram características bem distintas daquelas que vieram no período da construção. Desde seu início, em 1956, e por toda a década de 1960, foi a migração diferencial, marcada por um maior contingente do sexo masculino em idade produtiva, que mais a afluí para o DF, atraída pela oferta de emprego na construção civil. No decorrer dos anos 1960, os setores terciários e secundários juntos tornaram-se os maiores responsáveis pela afluência de migrantes, essencialmente do sudeste e Nordeste, tanto pela 
transferência dos servidores públicos, como, e ainda, pela continuada absorção do operariado na construção civil. (Indicadores sociodemográficos prospectivo para o Distrito Federal 1991-2030. 2009. p. 41)

Passado o período de grande fluxo migratório, devemos levar em conta a evolução natural da população local decorrente do crescimento vegetativo, composta pelos filhos, netos e bisnetos dos migrantes, pois, a cidade já entra na $3^{\text {a }}$ geração dos nascidos em Brasília. Essa componente demográfica já responde por praticamente metade do contingente populacional, de acordo com a analise dos dados feita pela CODEPLAN relacionada a pesquisa PNAD-IBGE 2007 que especifica que $48,6 \%$ da população local é formada pelos nascidos na cidade.

É dentro desse contexto que ocorre um substancial aumento na demanda habitacional do DF, primeiramente ligado à dificuldade de acesso à moradia imposta pelo governo federal e, posteriormente, local, já que, esses se consolidam como grandes detentores das terras, o que prejudicou os que para cá vieram; e depois pela dificuldade de se comprar a moradia, pois, os preços ficam cada vez mais elevados, fator que impossibilita tanto os que imigraram quanto os que nasceram na cidade de comprarem um lote ou mesmo uma casa.

\subsection{Perfis de renda da população do DF: Uma distribuição econômica das} Regiões Administrativas

O projeto de construção de Brasília atraiu pessoas de diferentes níveis sociais, culturais e financeiros, nos primeiros acampamentos é grande a quantidade de trabalhadores com pouca ou nenhuma instrução e precária situação de renda, mas também há um grande fluxo de comerciantes de trabalhadores técnicos e especializados, engenheiros, administradores entre outros e posteriormente uma grande parcela de funcionários públicos oriundos da antiga capital.

Esses trabalhadores definem em um primeiro momento as classes sociais da cidade, onde se tinha os proprietários das firmas de construção como a classe de maior poder econômico e os operários construtores conhecidos como "peões de obra" e ligados a eles os de menor. 
Os "peões de obra" e seus familiares, envolvidos em variadas atividades que serviam de suporte a construção como alimentação, serviços de segurança, higienização entre outras, em sua grande maioria eram originários de regiões do país de baixo desenvolvimento econômico, seja por propriedades físicas do local ou por carência de uma política que buscasse implantar atividades econômicas, sendo assim, muitas vezes não conseguiam emprego e chegavam a Brasília dispostos a enfrentar condições extremas de trabalho, como expõem Ribeiro(2008, p.153) "a possibilidade de aumentar o salário com um grande número de horas extras aparece claramente como o grande atrativo econômico para a massa de trabalhadores[...]".

Esses trabalhadores enfrentavam um ritmo frenético de trabalho, com poucas horas de descanso ou lazer sendo uma característica comum nessa época a prática da conhecida "virada", que ainda, de acordo com Ribeiro seria,

[...]um mecanismo ilegal de exploração, realizado por meio da extensão da jornada de trabalho e passível de ser considerado a forma mais aguda deste tipo de exploração. Normalmente implica trabalho durante 24 horas ou mais. Entrecortadas apenas por períodos dedicados à alimentação, frequentemente realizada na própria obra. (Ribeiro, 2008, p. 165)

A virada propiciava uma melhoria substancial no aumento da renda dos trabalhadores, porém apenas por um curto período se mostrando insuficiente para que a situação econômica deles pudessem manter se elevada por um período mais longo.

As péssimas condições de trabalho, moradia e alimentação acabava por minar os ganhos dos operários o que mantinha grande parcela dos trabalhadores dentro da faixa de menor renda entre a população da nova capital.

Após a retirada das moradias irregulares que ficavam próximo ao Plano-piloto e sua transferência para as recém criadas cidades satélites há uma concentração destes trabalhadores de baixa renda em uma determinada localidade, fator que ainda pode ser percebido quando se observa a atual distribuição das famílias de baixa renda no território do DF.

Ocorre uma média salarial e per capita mais elevada nas cidades próxima ao núcleo central e uma redução da renda naquelas mais afastadas, com exceção de algumas áreas habitacionais surgidas irregularmente e que mesmo mais próxima a este núcleo apresentam um baixo rendimento. O mapa de caracterização da população do DF em níveis de renda demonstra bem essa divisão. (Ver anexo 1) 
Dois estudos foram elaborado pela CODEPLAN utilizando como base dados informações coletados pela pesquisa PDAD/2004 realizada na área urbana das 27 regiões administrativas existentes à época.

O primeiro relatório divulgado foi o Indicadores de desigualdade social no $\mathrm{DF}^{3}$ do ano de 2007 que avaliou indicadores demográficos, de renda, condições dos domicílios, da educação e aspectos culturais. O Segundo foi a Síntese de Informações Socioeconômicas ${ }^{4}$ de 2008 que traz além das informações constantes do primeiro relatório, sob novo formato, a caracterização física da cidade.

O relatório da CODEPLAN(2007) distribuiu as regiões administrativas dentro dos perfis de renda pré definidos como demonstrado na tabela 2.

\section{Tabela 2}

\section{Distrito Federal por grupos de Regiões Administrativas segundo as faixas de renda per capita mensal -2004}

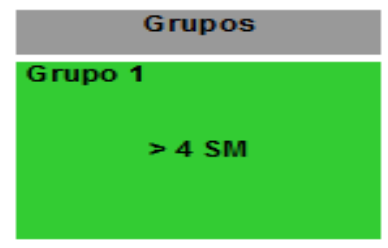

Grupo 2

$>2$ até $\leq 4 \mathrm{SM}$

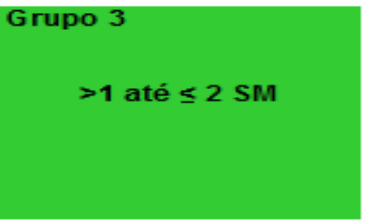

Grupo 4

$>0,5$ até $1 \mathrm{SM}$

Regiōes Ad mi nistrativas
RA XVI - Lago Sul
RA XXII - Sudoeste/Octogonal
RA XV III - Lago Norte
RA I - B rasilia
RA XXIV - Park Way

RA $X$ - Guará

RA $X X$ - Águas Claras

RA XI - Cruzeiro

RA III- Taguatinga

RA VIII - Núcleo Bandeirante

RA V -Sobradinho

RA XIX - C andangolândia

RA XXVI - Sobradinho II

RA II - G ama

RA XVII - Riacho Fun do

RA XIV - São Sebastião

RA IX - Ceilândia

RA VII - Paranoá

RA XII - Samambaia

RA XIII - Santa Maria

RA XV - Recanto das Emas

RA XXI - Riacho F undo II

RA XXIII - Varjão

RA IV - Brazlândia

RA VI - Planaltina

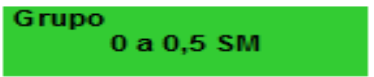

\section{RA XXV - Estru tural}

RA XVIII - Itapoá

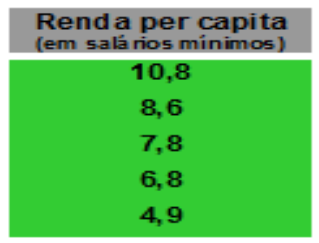

3,3

3,1

3,1

2,5

2,4

2,4

2,2

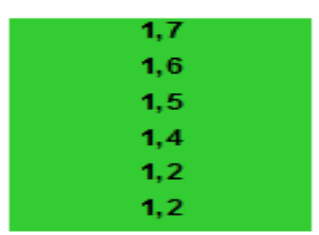

1,0

0,9

0,9

0,9

0,8

0,8

0,8

0,4

0,4

Fonte: Relatório CODEPLAN(2007)

\footnotetext{
3 E objetivo deste estudo identificar e traçar um paralelo entre o conjunto das RAs mais privilegiadas e aquelas cujas carências constituem um traço marcante que as posicionam no extremo oposto. As informações apresentadas neste estudo compreendem aspectos relativos a Demografia, Renda, Condições Domiciliares, Educacionais e Culturais nas Regiões Administrativas de maior e menor poder aquisitivo. Indicadores de desigualdade social no Distrito Federal pp.8-9

4 Síntese de Informações Socioeconômicas/ Companhia de Planejamento do Distrito Federal (Codeplan). Brasília : CODEPLAN, 2008. O estudo é apresentado em cinco capítulos: Caracterização do Território; Caracterização Político - Administrativa; Caracterização da População; da Economia; e, da Região Integrada de Desenvolvimento do Distrito Federal e Entorno - RIDE.
} 
A companhia faz uma distribuição das regiões da cidade em 5 classes baseando-se no indicador renda per capita mensal de cada uma das localidades pesquisadas, onde, os valores de referência utilizados são o de 0,5 salário mínimo como índice inferior e maior que 4 salários mínimos como superior.

Ainda de acordo com o relatório de 2007 o DF é a unidade da federação onde se tem a maior renda per capita do país, porém o que devemos considerar é que este índice elevado não significa uma melhor distribuição de renda.

Podemos inferir pelo gráfico 2 que ocorre um nível salarial elevado nos grupos 1 e 2 onde mais de 55,4\% e 33,6\% respectivamente percebem renda acima dos cinco salários mínimos e nos grupos 3, 4 e 5 um decréscimo com uma concentração maior que $68,1 \%, 80,7 \%$ e $98 \%$ respectivamente dos que recebem até cinco salários.

\section{Gráfico 2}

\section{Classes de Renda Domiciliar Mensal, por agrupamento de Regiões Administrativas - 2004}

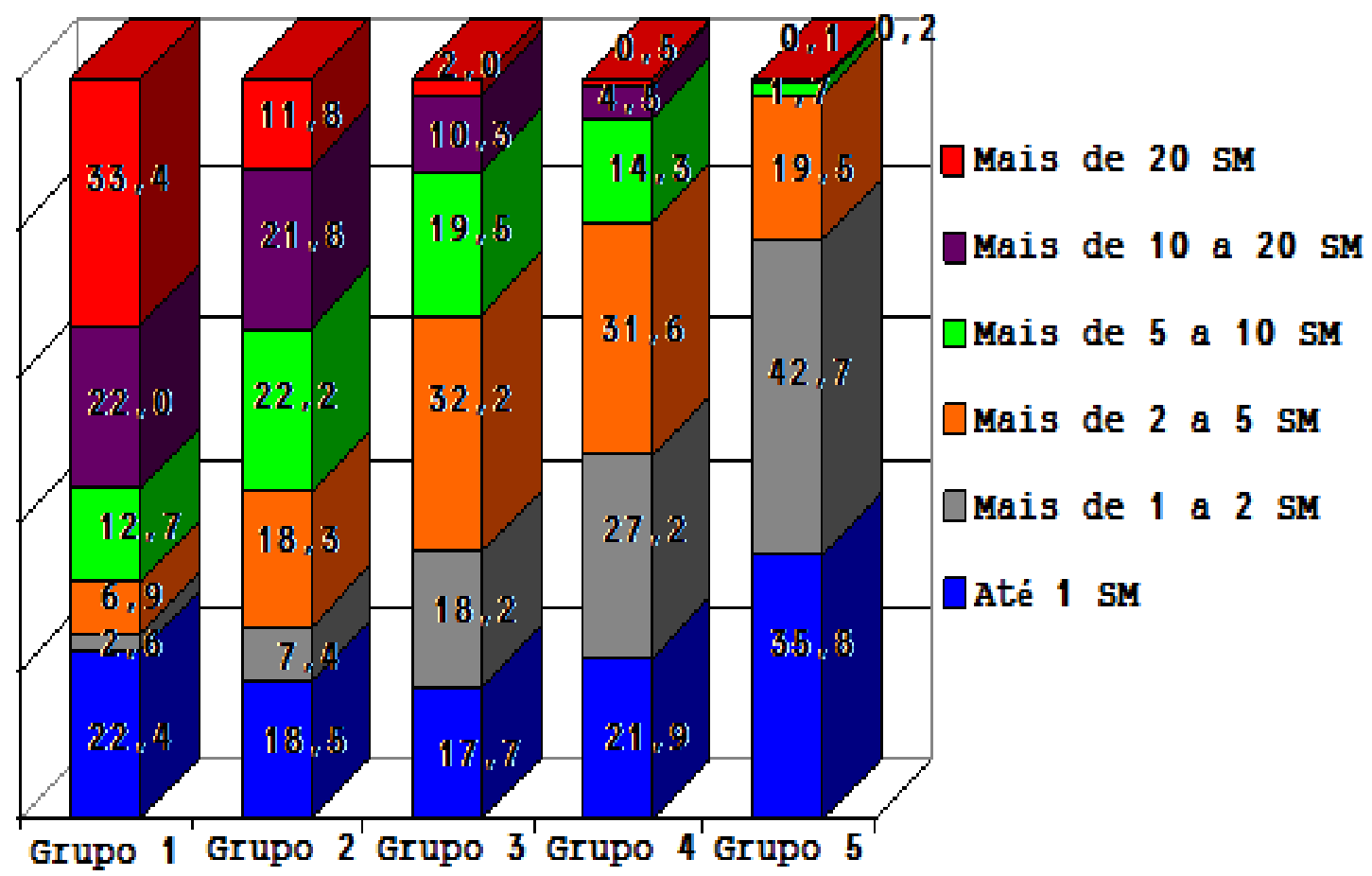

Fonte: Relatório CODEPLAN (2007) 
O universo a ser abordado por este trabalho é exatamente aquele que se situa na faixa de até 2 salários mínimos parcela que corresponde a $35,8 \%$ da população local, representado no gráfico 3.

\section{Gráfico 3}

Domicílios por Classes de Renda - Distrito Federal - 2004

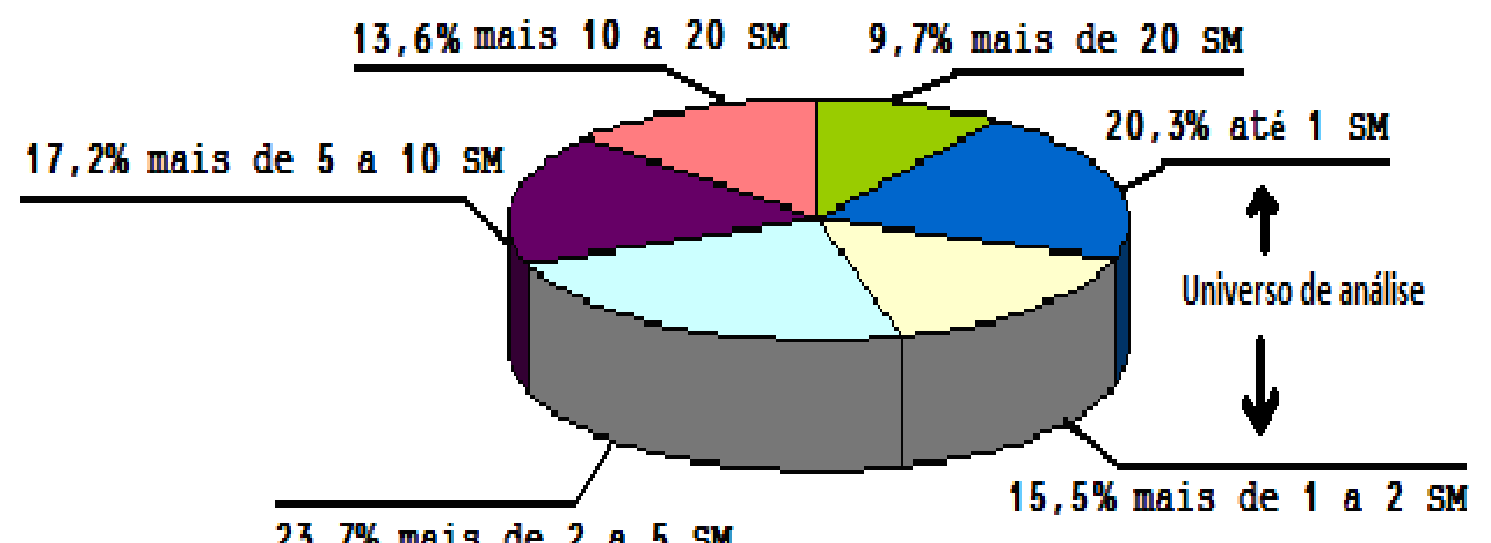

Fonte: Relatório CODEPLAN (2008)

É importante ressaltar que tal procedimento sofrerá uma demarcação territorial não sendo abordada toda a categoria que compõem o DF e sim aquela dentro de uma região específica e que se encontra situada dentro do terceiro grupo (tabela 2) , pois, a localidade a ser abordada, residencial Sol nascente, pertence a região administrativa de Ceilândia. (Ver anexo 1) 


\section{CAPITULO 2 - GESTÃO URBANA E DÉFICIT HABITACIONAL}

A gestão habitacional do DF é marcada por grande controle estatal e uma intensa política de segregação espacial no que se refere às famílias de menor renda, buscando sempre a melhor forma de conter a apropriação do território por essas famílias.

O rígido controle estatal faz surgir uma demanda habitacional significativa na classe de baixa renda. As famílias que compõe essa classe não conseguem rendimentos suficientes para adquirir uma moradia. Elas dependem de uma política habitacional que as contemplem, política essa que é feita de forma esporádica, ligada a objetivos políticos e em grande parte focada na expulsão das famílias do centro da cidade.

É a partir desse processo que surgem as cidades-satélites, que serviram e que ainda servem como solução habitacional para as populações de baixa renda, funcionando como receptoras da grande massa de operários que formavam a população inicial de Brasília e como aglutinadoras de grande parcela das famílias de baixa renda que compõe a cidade.

\subsection{Moradias para as famílias de baixa renda: Cidades-satélites e segregação}

O intenso fluxo migratório que ocorre logo nos anos iniciais de criação da nova capital faz surgir uns dos problemas que o governo queria evitar com a transferência da cidade para a região Centro-Oeste: um grande contingente populacional, de baixa renda, muito próximo ao centro político/administrativo do país. Esse fator obriga o governo a criar uma opção de moradia para os trabalhadores e suas famílias, que ali não poderiam (deveriam) ser mantidas.

Essa necessidade de assentar a grande massa de operários deu origem ao fator, possivelmente, mais marcante no que se refere à política de habitação para famílias de baixa renda adotada após o período inicial de construção: a segregação espacial. "A solução do problema de moradia dos pobres se fez com a exclusão dos trabalhadores do perímetro valorizado e planejado, forçando a segregação espacial", (FERREIRA, 1999, p.140). Buscou-se, dessa forma, afastar da área central 
aqueles que não se enquadravam na função definida para a cidade e que não possuíam um padrão de renda já estabelecido antes mesmo da inauguração.

De acordo com Ferreira (1999, P.140), "No centro, localizavam-se as funções ligadas ao centro do poder, enquanto a periferia abrigava os trabalhadores de baixa renda e as funções relativas à reprodução da força de trabalho envolvida na construção da cidade". Esse fator dá início a um projeto estatal de exclusão social ligado intimamente à expulsão dos trabalhadores para áreas periféricas ao centro, utilizando para isso a necessidade de moradia desses operários;

[...] a ação governamental na área específica da habitação sempre se deu no sentido de segregar e principalmente de controlar as classes populares, tanto pela forma como eram concebidos e localizados os conjuntos habitacionais, como, também pelas maneiras como eram os mesmos repassados à população. (GOUVÊA, 1991, p. 78)

O projeto original da cidade deveria ser preservado, a função primordial de Brasília deveria ser mantida, independente dos critérios que fossem utilizados. Isso só seria possível através da retirada das residências, as conhecidas invasões, das famílias de baixa renda que se alocavam no centro, mesmo sem a concessão governamental, onde, de acordo com Campos;

Em nome da ordem, respaldado por um plano urbanístico que entende a cidade como uma unidade funcional, espécie de empresa estudada previamente e submetida às regras de um ordenamento geral, luta-se contra o espontaneísmo e a desordem simbolizados nos acampamentos e as invasões então existente. (CAMPOS, 1991, p.100)

A cidade planejada, em sua síntese, não deixaria de representar o papel para o qual foi criada, mantendo longe dos conflitos os que nela residem. Como nos esclarece Peluso;

No espaço finito e fechado do Plano Piloto, envolto por extensas áreas verdes de posse do governo, estava tudo o que era necessário para o bemestar de seus moradores e para a função de Capital Federal. As mazelas dos grandes centros seriam afastadas dessa cidade burocrática, tranqüila e planejada. Encarregado de não permitir deturpações no Plano, a administração garantiria a equidade, a beleza e a harmonia, atuando neutra e racionalmente. (PELUSO, 2003, p. 9).

É a necessidade de assentar o grande número de famílias que existiam na época da construção de Brasília que faz com que as autoridades implantem as cidades-satélites bem antes do previsto, e que acabam por tomar forma diferente da planejada inicialmente,

O plano inicial era o de implantar cidades-satélites somente quando o Plano Piloto atingisse 500.000 habitantes. Entretanto, já durante a construção de Brasília, a necessidade de abrigar o contingente de operários e demais 
imigrantes levou ao surgimento precoce das cidades satélites. (GANEM et al., 2008, p.85)

Essas cidades seguiam, de certa forma, a racionalidade tão expressa no projeto de Brasília, porém, exerceriam uma função bem diferente daquela definida ao Plano-Piloto, como nos mostra Silveira;

As cidades-satélites constituíam-se em núcleos urbanos, foram promovidos pelo setor público do Distrito Federal e seguiram, em parte, os princípios e os modelos modernistas do Plano-Piloto, tornando-se cidades que abrigaram grandes contingentes populacionais de baixa renda, [...] (SILVEIRA, 1999, p. 149).

Ou mesmo na fala de Gouvêa;

[...] observa-se a clara intenção de se construir o Plano-Piloto para abrigar os funcionários mais graduados do governo, e as cidades-satélites, de padrão inferior, para servir de moradia para o restante da população, ficando patente desde o início a política discriminatória [...] (GOUVÊA, 1991, p.82)

Pois como nos lembra Doyle;

Há um equivoco quando se afirma que o plano de Lúcio Costa previa que "pobres" e "ricos" morariam próximos. Na verdade, houve uma oferta de residências no Plano Piloto para funcionários públicos de menor remuneração,

[...] o poder público sempre teve a preocupação de acabar com as favelas, não para resolver o problema, mas sobretudo para afastá-lo." (DOYLE,1996, p.117)

Desde o início, essas cidades ficaram marcadas pela precária infraestrutura, o que deixava claro que o governo não buscava conceder uma moradia digna aos trabalhadores de baixa renda, mas somente resolver a questão primordial que era a preservação do centro, livrando-o do grande número de invasões que se formavam ao seu redor.

Mesmo distantes, as cidades-satélites mantêm uma relação fixa com o Plano Piloto, na medida em que a implantação delas não fez gerar uma desconcentração das atividades econômicas que possibilite a absorção da massa de trabalhadores que as compõe, "[...] as cidades satélites, enquanto assentamentos importantes, não oferecem oportunidades de trabalho correspondente ao volume das respectivas populações ativas. (PAVIANI, 1991, p.121).

Essa política do governo de retirada das famílias de baixa renda é apoiada em um discurso que se baseou na melhoria da qualidade de vida das pessoas que residiam nas invasões, como nos mostra Pavianni (1991, p.126) "O discurso justificativo das transferências de favelados era o de que eles 'moravam da maneira 
mais precária: barracões de madeira velha [...]". O governo utiliza do seu próprio descaso em suprir as necessidades desses moradores como fator preponderante a ser resolvido, porém em outra localidade, que não próxima ao Plano Piloto.

O governo mostrava a outra face da cidade planejada, aquela que não aceitava em seu seio os brasileiros que não possuíam o perfil econômico para a comporem. "Brasília, ao mesmo tempo em que se tornou um símbolo do urbanismo moderno, se configurou como um modelo quase perfeito de segregação e controle espacial e social." (GOUVÊA, 1991, p.80). É apoiado nesse processo de segregação, que nega o centro da cidade à grande parte da população, que se desenvolvem as políticas de habitação do DF.

\subsection{As políticas de habitação do DF: Uma recorrente prática clientelista}

[...] para manter a 'face modernizante', as sucessivas transferências de favelados acabam por incorporar uma parcela (um tanto constrangedora e não assumida) da 'ideologia de Brasília'. (PAVIANI 1991, p. 127)

Passado o período inicial de implantação de várias cidades-satélites, com a oferta de um grande número de lotes distantes do centro da capital, a política de habitação apresentará, basicamente, duas faces.

A primeira, de controle populacional, reduz a oferta de moradias, acreditando que isso reduziria o fluxo migratório para a cidade, fator que não ocorreu, sendo muito comum nos governos militares, que viam a necessidade de manter o perfil estratégico da cidade longe de grandes contingentes populacionais. E a segunda, com grande oferta de moradias nos períodos próximos às eleições, fundando assim uma política clientelista, realizada em grande parte durante os vários governos Roriz, como mostrado em matéria do correio de 2008:

Roriz optou pela política de acomodar o máximo possível dos moradores de invasões. Criou a maior política de doação de lotes da história de Brasília, assentando em terrenos urbanizados perto de 100 mil famílias. As ações tornaram-se a marca da gestão de Roriz, que mais tarde conseguiu se eleger(...) ("Ocupação urbana" - Correio Brasiliense, 12/10/2008 p.40)

A política habitacional do DF, como nos mostra alguns autores, como Santos e Stumf (1996), Gouvêa $(1991,1996)$, entre outros, pautou-se por apresentar uma 
constante reprodução da segregação realizada dentro de uma concepção clientelista.

Farias (2000) nos dá uma idéia de como esse processo se realiza mais recentemente:

\begin{abstract}
Uma expressão característica do clientelismo é o voto mercadoria, ou seja, a relação de barganha, em torno de vantagens materiais, entre o eleitor e o cabo eleitoral (uma espécie de líder local, que cuida dos interesses de seus representados, principalmente junto às "autoridades públicas", fazendo às vezes de, segundo a expressão de Paulo Singer, um "advogado administrativo" da sua comunidade - uma vila, uma favela, um quadro associativo de um clube recreativo etc.). Controlando, em geral, uma centena ou uma dezena de votos, o cabo eleitoral os vende ao "político de clientela", que "não passa de um cabo eleitoral suficientemente poderoso". (SINGER, apud FARIAS, 2000, p.50)
\end{abstract}

Podemos resumir essa prática usando ainda da fala de Farias (2000, p.49), "[...] o clientelismo é a apropriação privada da coisa pública; a barganha do voto representa uma corrupção da democracia."

Essa característica se junta à política de remoção das famílias de baixa renda, adotado no período de construção/inauguração da cidade, acabando por se tornar uma constante dos governos que se sucediam no poder da capital. "Quando Brasília foi inaugurada, o processo de remoção se intensificou, tornando-se sistemática esta prática, pelos vários governos que se seguiram." (GOUVÊA, 1991, p.82), em certos períodos, ofertava-se moradia, em outros, simplesmente se despachavam os imigrantes de volta para sua terra.

Esse processo era efetuado, algumas vezes, de forma ríspida, onde se utilizava o aparato policial para a retirada dos moradores das invasões. Outras vezes tentava-se demonstrar que aquilo seria o melhor para as pessoas que estavam sendo removidas devido às péssimas condições das habitações em que moravam.

A prática de remoção não apenas segregou espacialmente aqueles que foram expulsos do centro, como também desempenhava uma forma de controle social à medida que dificultava o acesso da população ao Plano Piloto, como descreve Gouvêa;

[...] em um primeiro momento, o governo segregou física e socialmente as classes populares nas distantes e mal-equipadas cidades-satélites, desenvolvendo ao mesmo tempo uma política de controle social desta população, por meio da distância que separa os núcleos satélites do PlanoPiloto [...]. (GOUVÊA, 1991, pp.83-84) 
A promessa de moradia, independentemente do governante ou da época, passa a funcionar como moeda de troca, favorecendo, ora aqueles que querem conquistar o poder, ora aqueles que buscam manter-se no poder.

Os governos veem na necessidade de habitação uma forma de conquistarem a simpatia, e votos de um grande número de pessoas, tornando essa prática uma política "oficial" a medida que era, e continua sendo, constantemente utilizada.

Pode se observar duas características distintas na postura dos governantes, e de certa forma opostas, no modo como eles conduziriam o acesso à moradia por famílias de baixa renda. Primeiramente, o governante exercia um amplo controle sobre o acesso dessas famílias a habitações não às ofertando; e, posteriormente, modificava a política, ao se aproximar de pleitos eleitorais, disponibilizando grande número de residências para aquelas famílias, como nos mostra Gouvêa;

No Distrito Federal observaram-se, de forma cíclica, momentos de grande oferta de moradias em núcleos distantes do Plano-Piloto, intercalados por momentos de não oferta de habitações, salvo curtos períodos próximos às eleições, quando se buscou atender às reais necessidades da população, com interesses puramente eleitorais. (GOUVÊA, 1996, p.233)

É importante ressaltar que grande parte das moradias ofertadas para as famílias de baixa renda era em locais sem infra-estrutura adequada, colocando aquelas em total situação de penúria, até que um novo pleito eleitoral fizesse surgir o interesse governamental em melhorar a qualidade de vida dos moradores dos bairros "carentes". Gouvêa nos mostra bem a forma como ocorre esse processo;

Mesmo quando implantou infra-estrutura nos bairros populares, objeto da
política de erradicação de favelas, o fez com interesses eleitoreiros,
visando cooptar a população, servindo inclusive este processo para
desmobilizar os trabalhadores, pois, tais, iniciativas, mesmo não atendendo
às reais necessidades das pessoas, serviam como contemporização, que
aos poucos passava a ser vista pelos moradores como ganhos e não como
pagamento atrasado de uma dívida social, contraída no momento da
remoção. (GOUVÊA, 1991, p.86)

Lembramos ainda que esta política rígida e excludente não se repete no que se refere aos que possuíam maior renda, facilitando e muitas vezes suprimindo a lei, permitindo o total acesso à terra por aqueles que detinham renda suficiente para pagar por ela. De acordo com Gouvêa (1991, p.93), "O governo ao mesmo tempo que removia de forma violenta a população das terras próximas à sede do poder, alienava a particulares, sem licitação pública [...], áreas de sua propriedade[...]"

Até mesmo quando o governo se utiliza dos mecanismos legais para permitir o acesso à terra, a grande parcela da população não consegue adquiri-la, pois o 
fator mais importante que possibilita esse acesso é a renda que se possuí, como nos mostra Campos (1991, p.110), "O processo pelo qual a maior parte das terras são oferecidas no mercado [...] é a licitação pública, mediante realização de leilões. Isto dá à terra um caráter especulativo, porque as empresas maiores, com maior disponibilidade de capital -as incorporadoras- compram-na [...]".

Isso fará com que ocorra uma grande concentração de terras nas mãos daqueles que possuem maior renda e que, posteriormente, haverão de utilizá-las para construção de moradias de alto padrão e elevado preço, enquanto a maioria da população fica dependente de uma política habitacional que só se apresenta em curtos períodos e, na maioria das vezes, mediante interesses eleitoreiros.

Essa política de controle territorial, baseada em grande parte na não oferta de moradias a famílias de baixa renda, faz com que seja incrementada a cada dia a taxa do déficit habitacional ligado a cidade. É importante lembrar que a maior parte desse déficit está relacionada às diferentes necessidades de habitação que devem ser supridas pelos agentes governamentais e à dificuldade das pessoas auferirem renda suficiente para adquirir moradias por meios próprios.

\subsection{Déficit habitacional: Um problema social que marca o DF}

É uma expressão que se refere à quantidade de cidadãos sem moradia adequada em uma determinada região. Os critérios para definir o que seria "moradia adequada" variam. O economista Robson Gonçalves, do IPEA, utiliza três critérios para definir moradia inadequada:

- a rusticidade das estruturas físicas das habitações (uso de materiais não-duráveis e ou improvisados);

- a moradia não ser originariamente construída para habitação, adquirindo essa função apenas de forma esporádica ou improvisada;

- a coabitação (a existência de mais de uma família por residência). (Déficit Habitacional: Disponível em:<http://pt.wikipedia.org/wiki/D\%C3\%A9ficit_habitacional)

O problema habitacional em Brasília surge junto com a criação da cidade no centro do país. A grande massa de migrantes que chegava só conseguia moradia, inicialmente, nas áreas destinadas às construtoras, o conhecido acampamento. Esses locais serviam para concentração da mão de obra, o que reduzia custos diversos e desempenhavam o papel de "solução habitacional" (RIBEIRO, 1991, p. 32), lembrando que, no que se refere a esse segundo ponto, o "objetivo central é prover habitações coletivas para um grande número de trabalhadores sem família" (RIBEIRO, 1991, p. 32). 
É importante salientar que muitos dos operários que vinham para a cidade possuíam famílias em seus locais de origem e que, muitas vezes, elas se juntavam a esses trabalhadores após algum tempo.

Os acampamentos possuíam locais para os operários residirem, mas, na verdade, eles funcionavam apenas como uma forma de moradia esporádica, pois sempre que concluíam a obra a qual estavam destinados eram desativados, fato que acabava por deixar uma grande massa de trabalhadores sem moradia. Dessa forma, a pretensa "solução habitacional" tinha data para ser extinta, que em muitos casos coincidiu com o período de inauguração da capital.

Os outros trabalhadores que chegavam à cidade e não conseguiam uma moradia fornecida pelas construtoras, acabavam fixando-se em "acampamentos/favelas" (JÚNIOR e IWAKAMI 1991, p. 60), que serviam como uma forma recorrente de moradia aos migrantes. "Com o decorrer das obras, o afluxo de migrantes à procura de trabalho fez que surgissem acampamentos espontâneos [...], (JÚNIOR e IWAKAMI 1991, p. 60).

As invasões - termo utilizado pelos moradores em substituição ao termo favela - eram uma resposta a um déficit habitacional que se ampliava a cada dia, Júnior e Iwakami (1991) relatam que, em 1988, existia 140 invasões onde uma população de aproximadamente 150 mil habitantes residia. Os autores fazem questão de chamar a atenção para a situação da coabitação no mesmo período, "Se formos computar os fundos de lote, que na realidade são cortiços que abrigam até mesmo vinte famílias, a população subabrigada chega perto de 700 mil habitantes [...], (JÚNIOR E IWAKAMI, 1991, p. 69). Ou seja, essa forma de habitação mostrouse por muito tempo como única opção de moradia para os trabalhadores de baixa renda que chegavam à cidade.

Um fator determinante no que se refere ao acesso à moradia, no caso específico de Brasília, está ligado à propriedade das terras. Sendo o Estado o grande detentor das terras devido ao processo de desapropriação que houve, representado, primeiramente, pelo governo federal e posteriormente, pelo local, lembrando que algumas áreas da cidade ainda são de propriedade da União, têm-se um controle intenso sobre quais áreas poderiam e seriam ocupadas como esclarece Guia; 
formado pelo Distrito Federal (...) tem sido fortemente orientada pela intervenção estatal, seja com ações voltadas para a incorporação de terras ao setor produtivo (infra-estrutura viária, fábrica e áreas habitacionais), por meio de doações e concessões de terras, ou nas ações de gestão do território caracterizadas pela restritiva legislação urbanística e os investimentos em infra-estrutura urbana (...) (GUIA, 2006 p. 40)

Esse controle estatal torna muito limitado o acesso à moradia para os operários de baixa renda ligados à construção junto com suas famílias. "No Plano Piloto[...] não havia previsão de espaço para a população operária,[...], e que aqui permaneceu após a finalização das construções” (GUIA, 2006, p.42). Não era interesse do governo manter esse grande fluxo de migrantes dentro da área central da nova capital depois de passado o período de obras

[...] acreditava-se que boa parte da população migrante regressaria, Outros seriam absorvidos em atividades agrícolas nos arredores da cidade. É cabível pensar numa exacerbação do poder do planejamento de Estado, pois na verdade a maior parte desse lastro de população, certamente não considerado nas previsões técnicas oficiais, permaneceu e "fincou raízes"; não retornando ao seu passado falido e cheio de anseios na busca em configurar o grande sonho de esperança idealizado no nascedouro de Brasília. (OLIVEIRA, 2008, p.51)

Essa postura adotada pelo governo federal de não oferecer moradia digna às famílias de baixa renda que chegavam à cidade, que acabou se tornando uma característica governamental ao passar dos anos, fez com que a taxa ligada ao déficit habitacional na cidade se mantivesse elevada até os dias atuais, tornando-se uma das maiores do país.

De acordo com o Relatório da Fundação João Pinheiro ${ }^{5}$ (FJP), o déficit habitacional no DF em 2007 estava estimado em torno de 107.248, o que corresponderia a $14,6 \%$ dos domicílios particulares permanentes, sendo que, 105.202 seriam constituídos na área urbana e 2.046 na área rural. Desse total 6,1\% se refere à habitação precária; 39,7\%, à coabitação familiar; 48,2\% ao gasto excessivo com aluguel e 6,0\% ao adensamento excessivo dos domicílios alugados.

A FJP utiliza para composição do déficit duas variáveis principais, uma ligada à forma como se apresenta a moradia, e outra referente à necessidade de implementação de moradias;

\footnotetext{
5 Os dados referentes ao atual déficit habitacional no DF encontram grande diferenciação de acordo com a fonte pesquisada, tal fator pode ocorrer devido aos parâmetros que foram utilizados para cálculo da taxa. Os aqui demonstrados são referentes ao relatório do Ministério das Cidades realizado pela Fundação João Pinheiro no ano de 2009, que utilizou dados da pesquisa Pnad/2007 realizada pelo IBGE. Feito contato com ambas as instituições, não foi fornecida fonte com dados mais atuais. Déficit habitacional no Brasil 2007 / Ministério das Cidades, Secretaria Nacional de Habitação. - Brasília, 2009 129p. Projeto PNUD-BRA-00/019 - Habitar Brasil - BID; Elaboração: Fundação João Pinheiro, Centro de Estatística e Informações
} 
Déficit por reposição do estoque refere-se aos domicílios rústicos, aos quais deveria ser acrescida parcela devida à depreciação dos domicílios. Tradicionalmente, utilizando o conceito do IBGE, os domicílios rústicos são aqueles sem paredes de alvenaria ou madeira aparelhada. Em decorrência das suas condições de insalubridade, esses tipos de edificação proporcionam desconforto e trazem risco de contaminação por doenças aos seus moradores.

$\mathrm{E}$ déficit por incremento de estoque contempla os domicílios improvisados, parte da coabitação familiar e dois tipos de domicílios alugados: os fortemente adensados e aqueles em que famílias pobres (renda familiar até três salários mínimos) pagam $30 \%$ ou mais da sua renda familiar para o locador. (déficit habitacional no Brasil - 2007 p.16-17). (grifos do autor)

O relatório traz ainda a forma como estaria dividido o déficit habitacional urbano por renda média salarial dentro das classes que compõe a população do DF, como demonstrado na tabela 3 :

\section{Tabela 3}

\section{Distribuição do déficit habitacional na área urbana do DF por faixa de renda média familiar mensal}

\begin{tabular}{|c|c|c|c|c|}
\hline $\begin{array}{c}\text { Distrito } \\
\text { Federal }\end{array}$ & Atê 3 SM & $\begin{array}{c}\text { Mais de 3 a 5 } \\
\text { SM }\end{array}$ & $\begin{array}{c}\text { Mais de 5 a } \\
\text { 10 SM }\end{array}$ & $\begin{array}{c}\text { Mais de 10 } \\
\text { SM }\end{array}$ \\
\hline$\%$ & 84,5 & 8,0 & 4,3 & 3,2 \\
\hline
\end{tabular}

Fonte: Relatório FJP /IBGE PNAD/2007 p.29

O que podemos observar ao analisar a tabela demonstrada acima é uma maior concentração do déficit habitacional ligada às famílias de menor renda mensal, o que nos possibilita inferir a incapacidade dessas famílias de adquirirem moradia sem o auxílio do governo.

É importante frisar que o déficit habitacional não se refere necessariamente a não existência de moradias, como foi esclarecido em conversa com o professor Paviani $^{6}$, mas muito mais ao fato de muitas famílias de baixa renda não conseguirem acessar a moradia que existe. Dessa forma, o déficit habitacional está estritamente ligado à situação econômica, mais do que à real falta de moradia.

6 Conversa em 2009 sobre a implantação do setor Noroeste quando eu e um grupo de trabalho o entrevistamos sobre sua opinião em relação a implantação do setor. O professor nos chamou a atenção para o falso discurso referente ao déficit habitacional ligada a classe de maior renda. 
O professor Paviani nos chamou a atenção sobre a existência de um grande número de moradias fechadas, tanto na parte central de Brasília como nas demais regiões administrativas, e ainda outra grande parcela alugada, demonstrando que aqueles que possuem melhor condição financeira acabam adquirindo mais de um imóvel, que servirão como fonte de renda futura através da valorização e posterior venda, ou complemento da renda mensal através do aluguel.

Esse fator também é demonstrado no relatório da FJP, ratificando a posição adotada pelo professor e também por este autor.

Um fator que se destaca a cada nova atualização do estudo sobre o déficit habitacional é o grande montante dos domicílios vagos. (...)

Segundo a Pnad 2007, mais de $84 \%$ das unidades vagas no país estão em condições de serem ocupadas e devem constituir-se, basicamente, em estoque do mercado imobiliário. (RELATÓRIO FJP p. 35).

Alguns valores ligados a esses domicílios estão expostos na tabela 4:

\section{TABELA 4}

\section{Domicílios vagos em condições de serem ocupados e em construção na região do DF}

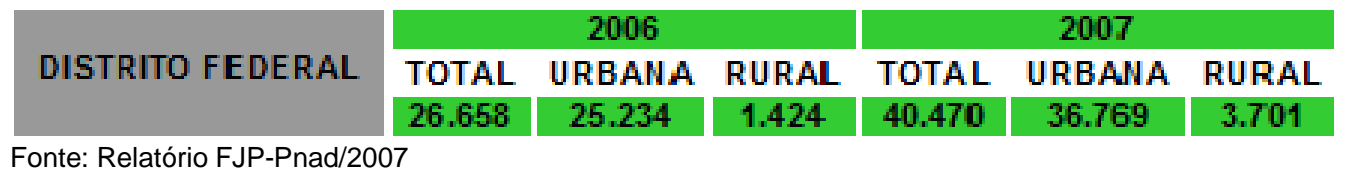

Ao analisar os valores da tabela acima, conclui-se que, apesar de existir um grande número de moradias vagas que poderiam reduzir substancialmente o déficit habitacional, elas não estão acessíveis à parcela da população que é a maior responsável pelo incremento do déficit às famílias de menor renda, como demonstra o relatório. "Especula-se que parcela substancial dessas moradias não seja adequada ao perfil do consumidor que realmente precisa ser atendido." (RELATÓRIO FJP p. 35).

Esse fator deixa claro que a construção de residências que não contemplem as condições financeiras das famílias de baixa renda gera um fenômeno habitacional conflituoso, ao passo que se tem, de um lado, uma grande quantidade de imóveis vagos e, de outro, uma grande parcela da população sem moradias por não possuir renda suficiente para adquiri-los.

Foi apoiada nessa postura governamental que surgiu o setor habitacional Sol Nascente, a não oferta de moradias que contemplasse as famílias que lá estão fez com que elas se apropriarem de terra públicas sem aval do governo. 


\section{CAPÍTULO 3 - PROCESSO DE OCUPAÇÕES IRREGULARES}

Neste capitulo abordarei um processo que se tornou rotineiro no DF por um longo período, o parcelamento de terras públicas, em área rural ou em reservas ambientais, e também de terras particulares sem o consentimento legal do governo, feito por particulares - "grileiros" - que objetivavam auferir um ganho econômico com a venda ilegal das áreas. É importante lembrar que a falta de ação do governo para coibir essa prática foi tomada pelos autores do processo como um consentimento informal.

A forma ilegal de ocupação ocorreu em áreas nobres, próxima ao Plano Piloto, e também foram implementadas nas localidades mais afastadas do centro, nas regiões administrativas, que atraíram grande quantidade de pessoas, principalmente de baixa renda que "fugiam" do aluguel e em muitos casos buscavam uma moradia no DF.

Será abordado o processo de Formação do Núcleo Habitacional Parque Sol Nascente, localizado na região administrativa de Ceilândia, que se destina a famílias de baixa renda que viram na compra de um lote no local a única forma de conseguir uma moradia na cidade.

\subsection{Ocupações Irregulares}

As políticas de habitação desenvolvida pelos vários governos do DF, pautada sempre no monopólio estatal das terras e privilegiando os que possuem maior renda, que conseguem adquiri-la, em detrimento das famílias de baixa renda, que ficam dependentes de programas de "doação de lote", que como demonstrado ocorrem em sua maioria próximo a pleitos eleitorais, faz surgir um mercado na cidade que redefiniria a forma de acesso a terra.

A ocupação urbana passa a seguir um caminho independente da ação governamental, dando origem a um grande número de parcelamentos irregulares por todo o território do DF, principalmente nas áreas de destinação rural e nas de proteção ambiental, como nos mostra Penna; 
de acesso à terra, (...), tomando para-si a iniciativa de parcelamento das APAs. (PENNA, 2003, p. 61)

As áreas que serviam para conter a expansão urbana próximo ao centro da Capital, em sua grande parte de reservas ambientais, pós década de 1980, começam a sofrer um intenso processo de ocupação residencial. Esse procedimento se repete nas outras regiões administrativas tanto em áreas públicas, de propriedade do GDF ou do Governo Federal, como também em algumas particulares que não foram objeto de desapropriação, "[...] ocorre a formação de um mercado imobiliário ilegal como novo mediador do acesso da população à terra na cidade, [...] desenvolvendo-se por meio de um processo acelerado de expansão sobre as áreas ambientais na periferia[...]."(PENNA, 2003, p. 62).

O território do DF que anteriormente se mostrava de forma concisa sob a tutela do Estado, que define a forma com se dará a ocupação urbana, passa a sofrer rupturas à medida que atores privados começam a agir intensamente como facilitadores no acesso a terra;

As rupturas do espaço homogêneo foram surgindo nos lugares onde se instalaram as condições para a fragmentação privada do espaço urbano, dando lugar ao surgimento e desenvolvimento de um mercado de terras mediante grilagem, ocupação e parcelamento ilegais da terra, tanto pública como particular, que foi sendo destinada ao uso residencial. (PENNA, 2003, p.67)

O Conflito Estado versus iniciativa privada está instaurado a medida que os particulares passam a desenvolver uma política habitacional em oposição a estatal e sem o consentimento legal do governo,

O estabelecimento e o fortalecimento da produção de uma periferia
particular, em oposição e enfrentamento àquela concebida pelas políticas
públicas, representam, principalmente, a ruptura do domínio estatal sobre a
propriedade e parcelamento das terras do DF. (PENNA apud PENNA,
2003, p.64)

De acordo com as autoras Ferreira (1999) e Peluso (2009) essas ocupações podem ser denominadas de "cidade ilegal" por não estarem dentro dos parâmetros urbanos e legais definidos e desenvolvidos pelo governo. Ainda de acordo com Ferreira;

A valorização das moradias no centro, a falta de oferta de imóveis para a classe média e a especulação imobiliária fizeram surgir a cidade ilegal. Trata-se do parcelamento clandestino de terras rurais para uso urbano, com ocupação e apropriação irregulares. (FERREIRA, 1999, p.141) 
O que podemos inferir da fala de Ferreira é que a dita demanda por habitação seria a responsável pelo surgimento dos parcelamentos irregulares. Entretanto deve se considerar que, grande parte dos parcelamentos foram adquiridos por pessoas de alto poder aquisitivo que não se enquadram no quadro do déficit habitacional, como mostrado anteriormente. Deixando claro o que nos expõe Malagutti;

[...] sabe-se por informação dos próprios compradores de imóveis clandestinos, que muitos deles compraram lotes, como forma de investimentos financeiro, numa forma sui generis de especulação imobiliária: investir em imóveis ilegais, na expectativa da regularização dos mesmos por iniciativa governamental. (MALAGUTTI, 1999, p.59)

Alguns fatores são determinantes para a mudança na forma de acesso a terra que deixou de ser monopólio do Estado. Um deles foi a extinção do sistema de provimento habitacional vigente até metade da década de 1980, como nos mostra Penna (2003), e que abre um grande precedente para a iniciativa privada atuar de forma mais contundente. "A produção da habitação [...] sai da construção pública e coletiva (financiada pelo BNH e FGTS até ser extinto em 1986) para o domínio privado, particular e bancário - instala-se o domínio da periferia auto construída, [...].” (PENNA, 2002)

Outro fator importante foi a incapacidade do governo em gerir de forma adequada as políticas de habitação de modo que elas atendessem as mais variadas demandas por moradia, dentro das devidas classes de renda em que se distribuí o DF, "[...] a grande falha governamental foi não ter percebido, a tempo que a Terracap não tinha condições de, sozinha, atender a essa demanda, utilizando parâmetros de preços que alcançassem os diversos níveis da população (MALAGUTTI, 1999, p.62), sendo que o órgão gestor do processo de venda de terras, no caso a Terracap $^{7}$ - Companhia Imobiliária de Brasília-, muitas vezes praticavas preços de venda de lotes bem superior as do mercado o que impossibilitou uma grande parcela da população de adquirir os terrenos.

Podemos inserir ainda dentro desse quadro de ocupação irregular outros fatores que possibilitaram o processo, como nos esclarece Malgutti, são eles:

\footnotetext{
7 A Terracap foi instituída por meio da Lei 5.861, de 12 de dezembro de 1972, mas só entrou em operação em 14 de agosto de 1973 , data adotada pelos empregados para comemorar o aniversário da companhia. A Terracap é uma empresa pública que faz parte da administração indireta do Distrito Federal, sendo regida por seu estatuto social e regimento interno, e pela legislação aplicável às sociedades por ações. Do capital da Terracap, 51\% pertencem ao DF e $49 \%$ são da União. Ao nascer, a Terracap herdou um patrimônio de 338.337 hectares de terras e a responsabilidade de administrar toda essa riqueza. Além de responder pela regularização fundiária dessas terras, foi the dado poderes para exercer atividades imobiliárias de interesse do DF. Assim, a Terracap passou a ser responsável por desapropriação, comercialização, arrendamento ou doação das terras do DF. Site da Terracap. Disponível em: <http://www.terracap.df.gov.br/internet/index.php?sccid=46\&sccant=45> acessado em: 10/08/2010.
} 
[...] a) a inexistência de mecanismos de controle público sobre o mercado ilegal de terras; b) a indefinição da estrutura fundiária do território; c) a debilidade das estruturas agrárias; d) falta de fiscalização e poder coercitivo na utilização de áreas protegidas ambientalmente. (MALAGUTTI, 1999, p.60)

Porém, Malugutti(1999) nos lembra bem e com clareza, que tal processo se desenvolveu por estar altamente vinculado a "omissão do Poder Público" e aos "interesses econômicos especulativos", descritos pela autora como "pilares" da "urbanização clandestina".

As ocupações irregulares se proliferaram por todo o DF, chegando ao ponto em que $25 \%$ de toda população da cidade reside nestas localidades de acordo com dados de 2006, da agora extinta Secretaria de Desenvolvimento Urbano e Habitação (Seduh).

Ainda no ano de 2006 a matéria "Terras sem dono" publicada no Correio Braziliense, de acordo com dados da Seduh, traça o seguinte quadro referente as áreas de ocupações, exposto na tabela 5 .

\section{TABELA 5}

\section{Ocupações irregulares no DF}

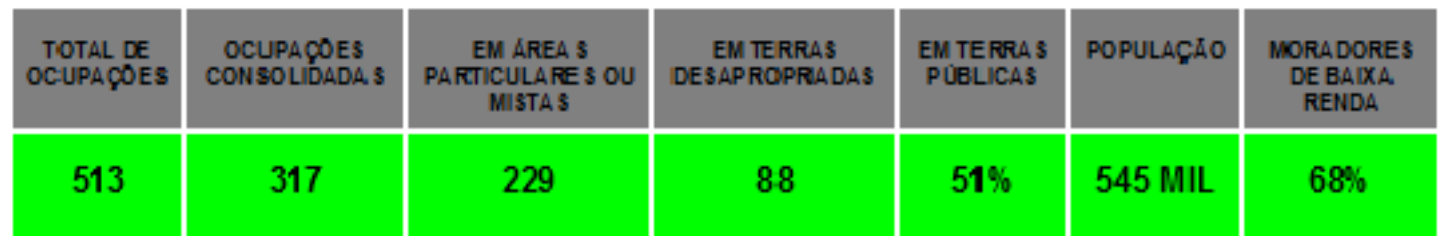

Fonte: Correio Braziliense. Terras sem dono, 17/02/2006. Seduh/2006

Essa situação chegou ao ponto demonstrado acima por falta de uma política habitacional realmente ligada às necessidades da população da cidade, visto que, o fluxo de migrantes de Brasília sempre se manteve em um patamar elevado, gerando uma constante busca por imóveis que vem sendo aumentada pela própria taxa de crescimento vegetativo da cidade, pois os filhos de Brasília já expressam uma grande parcela da população que busca por moradia.

Uma das conseqüências dessa má gestão na área habitacional é que os vários órgãos criados e extintos pelo governo para atuarem na área veem se envoltos em constantes denúncias de fraudes e favorecimentos, como mostrado recentemente em matéria do Correio Braziliense "Cooperativas sob investigação". 
Polícia Civil e Ministério Público apuram a participação de pelo menos 40 entidades em fraude com lotes distribuídos pela Codhab. Pelo menos 40 cooperativas habitacionais existentes no Distrito Federal estão na mira da Polícia Civil e do Ministério Público do DF e Territórios (MPDFT). As entidades são investigadas por suspeita de participação num esquema de venda de lotes inexistentes que teria lesado mais de mil famílias em Ceilândia, Santa Maria e Recanto das Emas. O golpe veio à tona com a deflagração esta semana da Operação Alfhein, na qual servidores, integrantes de associações habitacionais e até políticos são apontados como membros de uma quadrilha que agia desde 2007 e teria movimentado R\$ 9 milhões. ("Cooperativas sob investigação". Correio Braziliense. 14/08/20010 Caderno Cidades. p. 34)

Esse fator cria um verdadeiro sentimento de descaso na população que não vê credibilidade na política desenvolvida pelo governo, fazendo com que cada vez mais pessoas busquem outra forma de adquirirem lotes, abandonando assim a lista de inscrição no sistema governamental, e partindo para os parcelamentos irregulares que ofertam os terrenos a preço acessíveis para as várias classe de renda.

O que podemos perceber é que devido a uma constante inércia do governo na área de habitação a iniciativa privada acaba por assumir o papel de provedora de lotes,

[...] quando a Administração Pública não intervém com presteza e competência na oferta de moradia para as diversas categorias de rendas, ou quando não propicia os meios para o problema ser sanado pela iniciativa privada, os loteadores clandestinos intervém e acarretam maiores prejuízos a sociedade como um todo. (MALAGUTTI, 1999, p.57)

O quadro em que se desenvolveu os parcelamentos irregulares demonstra que a política de habitação desempenhada pelo governo deve ser revista, pois ela mantém os privilégios daqueles que possuem renda elevada e exclui os de menor renda, relegando-os aos parcelamentos irregulares em áreas periféricas longe do centro e com péssimas condições de infraestrutura sem o menor suporte Estatal.

Exemplo disso é o Setor Habitacional Sol Nascente, surgido na segunda metade da década de 1990, que passa a servir como setor agregador de grande parte da população de baixa renda de algumas regiões administrativas do DF e até mesmo do entorno. É esse processo de formação e consolidação do setor que mostraremos adiante. 


\subsection{Núcleo Habitacional Parque Sol Nascente: Parcelamento irregular de famílias de baixa renda}

O Núcleo Habitacional Parque Sol Nascente (NHPSN) ou como a maioria dos moradores preferem Setor habitacional Sol Nascente (SHSN), até mesmo por desconhecerem a lei que regula o núcleo, pertence à região administrativa de Ceilândia, cidade localizada a $27 \mathrm{~km}$ do Plano Piloto, implantada na década de 1970, como resposta a demanda habitacional dos operários da construção e solução do Estado para extinguir a grande quantidade de invasões que surgiam em volta do núcleo central, dentro do processo de criação das cidades satélites já abordado.

Como nos explica Malagutti (1999, p.63): "A má distribuição de renda amplia o cordão dos excluídos sociais e os empurra para a periferia, acarretando, assim, uma constante procura por loteamentos clandestinos." É essa intensa procura aliada a interesses econômicos que faz surgir o núcleo habitacional.

O setor habitacional está localizado à aproximadamente $35 \mathrm{~km}$ do PlanoPiloto, é destinado a famílias de baixa renda e a sua forma de consolidação foi através do parcelamento irregular de áreas particulares e públicas, sendo essas últimas em sua maioria áreas rurais e de proteção ambiental, pois como nos conta Penna;

\footnotetext{
Os lugares valorizados da cidade, não são somente os privilegiados pela beleza da arquitetura, da qualidade de vida, [...]. Tanto os lugares periféricos, menos qualificados técnica e socialmente (que ainda não possuem os chamados bens de consumo urbano: rede de água, luz, esgoto, telefone, etc.), quanto às reservas ambientais, [...], estão repletos de valores que fragmentam e hierarquizam funcionalmente todo seu território, numa imensa mancha urbana, onde se localizam os projetos de expansão urbana [...] (PENNA, 2002, p.3).
}

As famílias que compõe o setor viviam em sua maioria sob o regime de coabitação (aluguel ou casa de parentes) nas várias regiões administrativas do DF, em especial na de Ceilândia, ou do entorno de Brasília. As famílias que moravam no entorno do DF estavam interessadas em viver em uma área dentro de Brasília e mais próxima ao centro da cidade, isso possibilita a redução de gastos com transportes, economia do aluguel e permite a utilização da rede de atendimento do DF, como escolas e hospitais. 
“Eu queria morar no DF pra melhorar as condições, lá na Barragem não tem nada, aqui podemos ter escola e tem os postos (de saúde), fica mais perto..." (Ana B. Moradora da ch.02)

As famílias que moravam nas diversas regiões administrativas da cidade buscavam uma forma de pararem de pagar o aluguel ou mesmo de deixarem de viver na casa de parentes.

O setor surgiu na segunda metade da década de 1990, porém, foi após o ano 2000 que ocorreu uma atividade mais intensa de apropriação de terras na área, o parcelamento ocorreu devido a atividades de particulares - conhecidos como grileiros- que vendiam pequenos lotes, em áreas públicas de propriedade da Terracap, em algumas chácaras particulares e também em área de preservação ambiental;

Os grileiros que parcelaram irregularmente a área usavam documentos falsos, como cessões de direito real de uso, para ludibriar os compradores. Sem fiscalização adequada, a invasão cresceu e se alastrou até em áreas de preservação permanente como bordas de chapada. (Nove anos vivendo ao Pôr do Sol. Correio Braziliense. 30/08/2009. caderno Cidades, p.42)

Muitos moradores do setor adquiriram lotes na área mesmo sabendo que era ilegal, pois acreditavam que era a única forma de conseguirem uma moradia.

“Eu nunca me inscrevi pra ganhar lote, ouvi falar que não dava em nada então deixei de lado." ( Raimunda moradora da chácara 73).

Outros não acreditavam mais na possibilidade de serem contemplados pelo governo com a entrega de um lote.

“Meu companheiro já foi chamado pelo Idhab, em 1999, levou todos documentos, rodamos em nove cartórios pra juntar tudo, em toda Brasília e nunca foi chamado, já estamos em 2010, acho que não saí mais" (Mãa Iraneide, moradora da chácara 78).

Existem duas característica comuns entre os moradores entrevistados, independente dos anseios pessoais. Primeiramente todos possuíam o mesmo objetivo que era deixar de viver sob o regime da coabitação (aluguel/casa de 
parente) adquirindo uma moradia própria possibilitando assim uma melhoria na renda familiar.

“ Eu morava de aluguel na Ceilândia Norte, compramos o lote pra poder parar de pagar, a gente ficou apertado no começo, tinha que construir a casa mas depois foi ficando melhor..." (Ana moradora da chácara 05).

A outra característica, que é consenso entre os entrevistados, é o fato de não se considerarem invasores de terras públicas, pois, todos compraram o lote. Alguns de grileiros outros, de uma cooperativa. Não souberam informar qual cooperativa e a qual órgão estava vinculado, possivelmente era uma criação dos grileiros para tentar transmitir legalidade aos possíveis compradores.

“Não sou invasora, comprei o lote, pode ter sido por uma ninharia mas eu paguei por ele... (Mayara moradora da chácara 23)

"Eu comprei o lote não invadi, teve gente que invadiu e se deu bem..." (Euricléia moradora da ch. 60)

“Comprei o lote de uma cooperativa... (Mª Iraneide, moradora da chácara 78)

Apesar de terem adquirido o lote em áreas públicas e de preservação a figura de invasor não é aceita por eles, visto que, tiveram que pagar pelo lote, valores entre $R \$ 2.000,00$ e $R \$ 4.500,00$ pagos sempre com uma entrada e o resto parcelado em poucas prestações, dessa forma o vendedor grileiro, sabendo da irregularidade que praticava, não criaria um vinculo longo com o comprador.

Os moradores acreditam que já que pagaram pelo lote, independente de quem os vendeu, eles tem todo o direito sobre o terreno. Ignoram o fato de que, quem fez a venda, não era o proprietário das terras não podendo assim fazê-lo.

Atualmente existem aproximadamente 80.000 habitantes no local, que se distribuem em lotes de 125 a $180 \mathrm{~m}^{2}$ em sua maioria, em uma área de aproximadamente 845 hectares. 
A imagem 1 demonstra a dimensão do setor com a área habitacional demarcada em vermelho. A imagem 2 é uma representação parcial do mapa ambiental do DF do ano de 2006

Se compararmos as imagens 1 e 2 podemos ter uma real noção da área de preservação que foi atingida pela implementação do setor.

\section{Imagem 1}

Poligonal da área ocupada pelo setor no ano de 2008 em vermelho

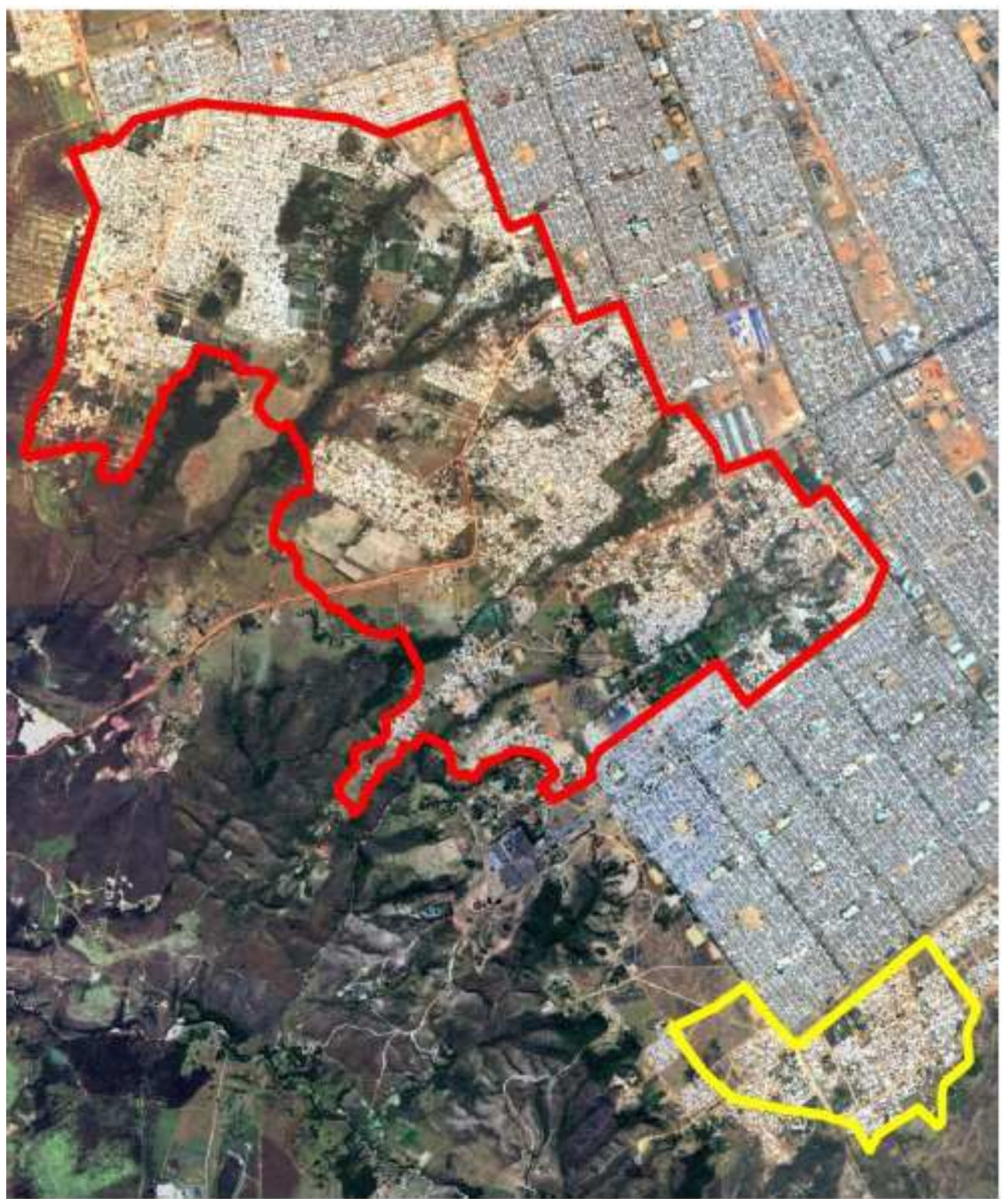

Fonte: Apresentação do programa habitacional do GDF 2008/2010 
Imagem 2

Representação parcial do mapa ambiental do DF de 2006

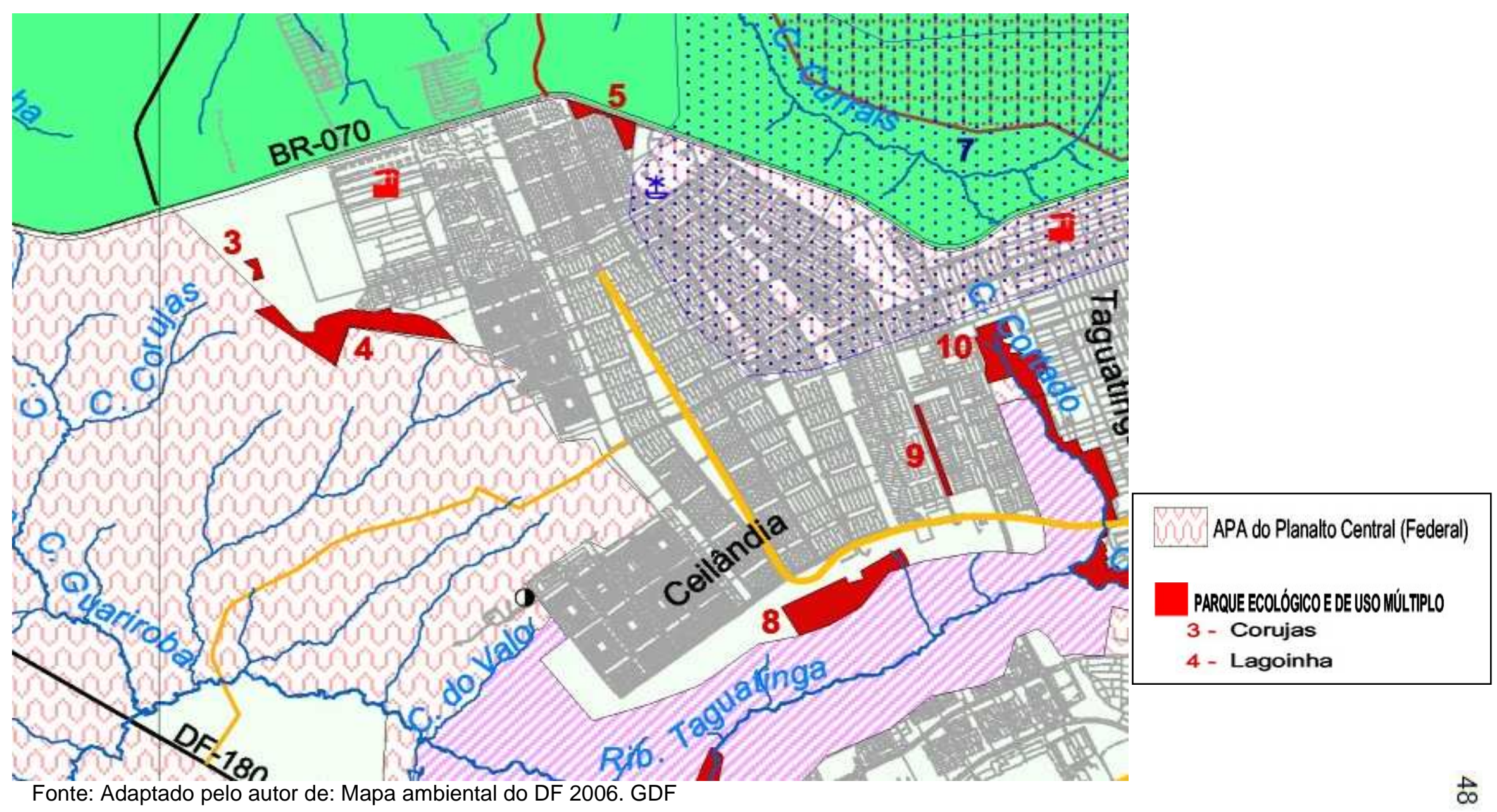




\subsubsection{Perfil de Renda}

Ao avaliarmos o mapa do perfil de renda do DF percebemos uma inconsistência para o setor habitacional por estar situado na cidade de Ceilândia ele aparece no mapa apresentando uma renda mensal per capita maior do que a verificada nas entrevistas na localidade.

Possivelmente tal fator se deva ao método utilizado na construção do perfil de renda do DF, feito de forma a agregar todos os bairros de uma região administrativa achando assim uma média para a área pesquisada. Isso possivelmente causou uma elevação na taxa de rendimento médio do Sol Nascente.

$\mathrm{Na}$ representação da cidade por grupos define-se a renda média per capita da cidade de Ceilândia entre maior que 1 salário mínimo- sm até $2 \mathrm{sm}$ (ver Anexo 1). Acredito, porém, que a renda familiar média per capita do SHSN se assemelhe mais a de cidades como Itapoã e Estrutural, que por representarem regiões administrativas independentes tiveram seus dados abordados de forma separadas, e que possuem renda média per capta entre 0 e $0,5 \mathrm{sm}$.

No grupo entrevistado apenas uma família atingiu o valor de $0,5 \mathrm{sm}$ per capita mensal, todas as outras ficaram abaixo desse valor.

Porém seria necessária uma pesquisa mais aprofundada com uma parcela maior de famílias para confirmar tal afirmação.

É importante lembrar que á época da pesquisa que construiu o perfil econômico do DF, PDAD/2004 (op. cit.), o valor do salário mínimo correspondia a $R \$ 260,00$ atualmente o valor está em $R \$ 510,00$ essa diferença não interfere na definição da renda local, pois a base é o salário mínimo em si, e não o poder de compra que ele pode representar.

\subsubsection{Conhecendo o Sol Nascente: Infra-estrutura e equipamentos públicos}

Uma das dificuldades encontradas ao andar pelo setor é a desorganização dos endereços. Percebi que não necessariamente a chácara 10 encontra-se ao lado da 09 ou da 11. Não existe um sistema padronizado para o endereçamento das chácaras, algumas que já existiam, foram divididas em conjuntos e outras que surgiram definiam a sua própria nomenclatura. 
Encontrei ainda algumas referências a condomínios (ex: condômino Gênese) e também a quadras. Pude perceber através de uma vista de uma área mais elevada que a parte definida como centro do Sol Nascente, as quadras (definidas assim por mim) até seguem uma padronização nas suas ruas, porém ao adentrar as vias mais internas do setor, essa padronização vai se tornando menos perceptível, devido a forma como se deu a ocupação. (Ver figura 1)

O núcleo habitacional é extremamente carente no que se refere à infraestrutura urbana e equipamentos públicos. Relacionarei aqui algumas das áreas que trazem grandes transtornos para a comunidade local, devido a condições precárias no atendimento ou mesmo a inexistência do item descrito.

Entre as aqui citadas as que mais se destacaram como prioridade, por apresentarem maior deficiência, estão a segurança e o saneamento básico (esgoto).

\subsubsection{Educação}

Possui duas escolas sendo uma localizada na área central do setor e outra próxima ao setor P.norte, na área conhecida como Vaquejada.

$\mathrm{Na}$ escola central, Centro de ensino fundamental (CEF) 66, (ver figura 2) o ensino é apenas de educação infantil e fundamental até o $6^{0}$ ano, com aproximadamente 1500 alunos e uma lista de espera de mais de 300 , o que demonstra a incapacidade de atender toda a demanda da localidade.

$\mathrm{Na}$ escola da Vaquejada, CEF 28 (ver figura 3), além da educação infantil ainda se têm o ensino fundamental até o $9^{\circ}$ ano, apresenta situação semelhante à central, com aproximadamente 1200 alunos e uma lista de espera de mais de 200. É importante observar que esta escola atende ainda parcela da população do P.norte que mora próxima, não sendo exclusiva do setor Sol Nascente.

Ambas as escolas apresentam boas condições físicas, por serem construções novas, porém apresentam grande dificuldade em manter um quadro fixo de docentes, pois mais da metade dos professores são do regime de contrato temporário. 
Os adolescentes que cursam o ensino médio devem deslocar-se para escolas na Expansão do setor "O", setor Qnq e setor P.norte. Não existe o programa de Educação de Jovens e Adultos no setor, o que origina grande reclamação dos moradores.

"Eu e minha filha íamos estudar lá na expansão, por que, aqui não tem EJA, mas era muito longe e de noite era perigoso, ai nós resolvemos largar,[...]" (Dona Regina Moradora da chácara 71)

Demonstrado também na fala da Vice-diretora da CEF 66

"Existe uma demanda enorme pelo EJA, nós tínhamos duas turmas de alfabetização para adultos, mas por problemas técnicos foram cancelas $e$ não voltaram mais. A população sempre vem aqui querendo saber quando vai ter, mas não temos como confirmar, falta pessoal, e segurança, [...] (Vice-diretora da Escola 66 central)

\subsubsection{Saúde}

Não existem postos de saúde no SHSN, como também não há nenhuma outra atividade governamental que busque atender a população local no que se refere a saúde, não existem programas de visita domiciliar ou focados em doenças especificas, ou mesmo acompanhamento de gestantes.

"Eu tive filho há dois meses todo o acompanhamento foi feito no posto da $Q$, aqui não tem nada, toda vez que quero consultar meu filho levo lá no posto ou no hospital direto, é muito difícil, é longe e ele ainda tá mamando tenho que andar muito." ( Graça Moradora do SHSN - atendente da prefeitura comunitária)

Os moradores devem procurar postos de saúde em outros localidades para consulta e para participarem de grupos de prevenção e tratamento de doenças como Diabetes e Hipertensão . 


\subsubsection{Segurança}

Existem dois postos de polícia um na entrada da avenida principal do SHSN (ver figura 4) e outro na área próximo ao P.norte - Vaquejada- o que fica na entrada principal atende além do setor ás áreas próximas como algumas quadras do setor $Q$, toda a $Q n r$ e ainda algumas chácaras, possui apenas uma viatura, sendo constantemente alvo de reclamações.

"Toda vez que a gente liga lá no posto eles falam que não tem como atender, diz que não tem viatura, que não tem policial, devia fechar logo aquilo lá, não serve de nada [...] os marginais fazem o que querem aqui." ( Breno Morador da chácara 86)

Podemos perceber a necessidade de mais policiamento no local também pela fala de um dos policiais do setor,

"Infelizmente nós só temos uma viatura para cobrir toda a área, e muitas vezes não temos como atender a certas ocorrências, pois, ela já está empenhada em outra atividade [...]" (Policial atendente do Posto na entrada da via principal)

\subsubsection{4 Água - Luz - Esgoto - Coleta de Lixo}

Está em fase de implantação no setor a água de origem da Companhia de água e esgoto de Brasília (Caesb), grande parte da comunidade já possui instalada em suas casas água regular, (ver figura 5), fator esse que traz não só mais comodidade para os moradores como reduz a possibilidade de adquirir doença provenientes de fontes contaminadas.

A energia do local é fornecida pela Companhia energética de Brasília (Ceb) (ver figura 6), grande parte dos "gatos" foi desfeito, porém, ainda existe em algumas residências, que acabam sofrendo queda de energia por causa da inconsistência na rede incapaz de suportar as ligações clandestinas. 
Não existe sistema de saneamento básico como redes de esgoto, ainda existem fossas e muitos dejetos são lançados na rua.

A rede de coleta de águas pluviais ainda não foi instalado, o que deixa as ruas todas com buracos na época da chuva, causando ainda grande quantidade de enxurradas de acordo com relatos de moradores (ver figura 7).

A coleta de lixo é feita pela empresa contratada pelo GDF com caçambas e não com o caminhão comum de coletas, porém essa não mantém uma rotina constante, deixando de passar em algumas ruas e também em alguns dias, o que possibilita o surgimento de depósitos de lixo em plena rua. (ver figura 8)

\subsubsection{Asfalto - Transporte}

Apenas a avenida central do SHSN possui asfalto, na verdade todo o asfaltamento da avenida encontra-se danificado, com grandes buracos o que exige dos motoristas verdadeiros malabarismos para transitar no local. Todas as demais ruas são de terra, propiciando a formação constante de poeira. (ver figura 9).

O sistema de transporte coletivo atende o setor, porém, passando apenas na avenida principal, fazendo com que grande parcela da população desloque-se até lá, com poucas linhas e grande intervalo entre um ônibus e outro, o que gera grande descontentamento nos moradores, não existem paradas cobertas em todos os pontos.

\subsubsection{Lazer}

Não existe nenhum centro que possibilite a prática de esportes pela comunidade nem quadras poliesportivas. $\mathrm{Na}$ área próxima a vaquejada tem se a construção de uma vila olímpica para atender a região, mas que está distante aproximadamente $5 \mathrm{~km}$ da área central do setor. A vila atenderá ainda moradores do P.Norte, Setor Q, QnR e Expansão. As obras encontram-se parada sem previsão de retorno e entrega a comunidade (ver figura 10). 
O que pude constatar nas visitas que fiz ao Núcleo Sol Nascente foi uma extrema carência relacionada a todas as áreas que deveriam ser supridas pelo governo local. Faltam políticas públicas para atender a população local em todos os setores.

\subsubsection{Legalização}

Em Outubro de 2000 o então governador do GDF, sancionou a lei complementar no 330 que criou o Núcleo Habitacional Parque Sol Nascente; Art. $1^{\circ}$ Fica criado o Núcleo Habitacional Parque Sol Nascente, localizado entre os Setores P Sul, P Norte e Quadras QNQ, na Região Administrativa de Ceilândia - RA IX, [...] ( Lei complementar № 330. 19/10/2000), sendo objetivos da lei, regularizar a situação das moradias construídas no local, evitar que novos parcelamentos fossem feitos na área, preservar flora e fauna próximos e ainda desenvolver social e economicamente o Núcleo habitacional.

Em visita ao setor, dez anos depois de criado, o que pude perceber é que grande parte dos objetivos expostos na lei nunca saíram do papel, principalmente no que se refere a controle de novas invasões ou parcelamentos.

Ao andar pelo Sol Nascente é facilmente avistado placas de venda de lotes (ver anexo 12). Ao ligar em um dos telefones expostos para me informar sobre a situação do lote, o vendedor me informou que se tratava de uma área nova que estava sendo "realocada" para moradias.

Mais recentemente o Plano diretor de ordenamento territorial (PDOT) 2009 da cidade que foi aprovado define o setor como Área de Relevante Interesse Social (ARIS), de acordo com o documento essas ARIS são assentamentos informais ocupados predominantemente por população de baixa renda e por tal motivo tem prioridade na regularização fundiária. Sendo ainda que, o governo se exime de cobrar da população local valores referentes a transferência de propriedade da terra. (Ver anexo 13)

O processo que deu origem ao núcleo continua ocorrendo, de forma mais lenta diferente de épocas anteriores. Possivelmente o motivo continua 
sendo ainda a falta de política na área de habitação para famílias de baixa renda, que encontraram no setor a solução de moradia, mesmo tendo que enfrentar inúmeras dificuldades estruturais do local, mas que parecem menores para os moradores por eles estarem agora no que lhes pertence.

"O governo não se importa em dá infra-estrutura para que as pessoas vivam com dignidade, pelo menos agora tenho minha casa [...]" (Euricléia moradora da ch. 60) 


\section{CONSIDERAÇÕES FINAS}

Gostaria de iniciar está parte do trabalho relembrando um artigo de suma importância presente na Constituição Federal de 1988 - a Constituição Cidadã - em dois momentos distintos.

Art. 6ำ São direitos sociais a educação, a saúde, o trabalho, o lazer, a segurança, a previdência social, a proteção à maternidade e à infância, a assistência aos desamparados, na forma desta Constituição (CF. 1988. Título II Capítulo II Dos Direitos Sociais - Redação Original)

Art. 6 São direitos sociais a educação, a saúde, o trabalho, a moradia, o lazer, a segurança, a previdência social, a proteção à maternidade e à infância, a assistência aos desamparados, na forma desta Constituição (CF. 1988. Título II Capítulo II Dos Direitos Sociais - Emenda feita em 2000) (Grifo do autor)

Podemos perceber que o constituinte em 1988 não se preocupou em relacionar a moradia entre os direitos sociais que deveriam ser garantidos a todos os cidadãos.

Possivelmente naquele momento aqueles que se responsabilizaram pela elaboração da Carta Magna não vislumbravam que a moradia devesse ser considerada um direito social, mas como grande parcela da população encontrava-se sem condições de adquiri-la, acertadamente este tema foi revisto e acrescido entre esses direitos. Deixou claro que todo cidadão tem direito a sua moradia e que o Estado deve criar formas para garantir que isso ocorra.

Porém, mais do que o direito, a moradia de fato, deve ser garantida a todos, tendo se especial atenção as famílias de mais baixa renda. Se essas não possuírem os meios necessários para adquirir uma casa é obrigação do Governo provê-las.

Políticas de habitação que respondam as necessidades das pessoas de baixa renda devem ser criadas e implantadas constantemente, buscando um aprimoramento que as torne cada vez mais capazes de responder aos reais anseios desta população.

No DF, as políticas de habitação desenvolvidas mostraram se excludentes, deixando sem atendimento os que mais necessitam, os de menor renda. Elas privilegiam aqueles que possuem rendimentos mais elevados possibilitando a eles adquirirem lotes através de um processo licitatório, onde 
os altos valores dos terrenos automaticamente excluem a classe de menor rendimento.

A preservação do centro da capital como projeto político segregou a maior parte da população em cidades distantes do Plano Piloto, com pouca ou nenhuma estrutura, no período pré e pós inauguração de Brasília, através dos programas de erradicação de invasões.

Essa segregação inicial, que não mais deveria ter sido repetida, tornouse uma constante na política de habitação local, que impossibilitava ao cidadão de menor renda adquirir uma moradia na área que deveria ser preservada, mantendo-os longe, na maioria das vezes, de seu trabalho, pois grande parcela da atividade econômica da cidade encontrava-se e permanece concentrada no Plano Piloto.

Novas invasões surgiam pela cidade, porém passaram a ser toleradas até certo ponto. Apesar de todos os problemas que as famílias enfrentavam não era ofertado de forma alguma moradia a elas, mostrando uma das face da política de habitação que tomaria conta da cidade, a não oferta de moradia a famílias de baixa renda.

A outra face que comporia essa política, era a focada em interesses eleitorais, como ofertar moradia em períodos próximos a eleições garantido assim uma grande parcela de votos que elegeriam ou reelegeriam um candidato em questão.

Tem se agora no DF a "política da moeda", em que dependendo do período em questão o governante vai mostrar sua face de cara ou coroa, ofertando ou não moradia de acordo com seus interesses, mas lembrando sempre que em nenhum momento deixa de ser a mesma moeda.

A prática de ofertar lotes próximo a pleitos eleitorais não respeitava a nenhum critério pré definido, baseava-se somente em oferecer a maior quantidade de lotes possíveis a uma grande parcela da população de baixa renda, fator que, com o passar do tempo gerou certa descrença na política de habitação governamental entre aqueles que se inscreviam nas famosas listas de lotes e que a muito aguardavam serem contemplados.

Uma grande quantidade de famílias que viviam em invasões ou em coabitações foram atendidas com o lote "dado pelo governo", demonstrando posteriormente sua gratidão nas urnas. Enquanto outra parcela da população 
mostrava-se insatisfeita com a forma como o governo desenvolvia sua política de habitação, privilegiando apenas os que invadiam as terras públicas.

Mesmo desenvolvendo essa política clientelista o déficit habitacional relacionado as famílias de baixa renda do DF ainda exibia taxas elevadas, pois não era oferecida para as famílias não contempladas uma forma de adquirirem o tão sonhado lote, obrigando-as a viverem sob o regime de coabitação, onde o aluguel é responsável por minar boa parte de seus rendimentos.

Esse fator, juntamente com interesses econômicos de alguns, levam as pessoas a adquirirem lotes de formas irregulares na cidade. Cada família responsabilizar-se-ia por adquirir sua moradia independente da política desenvolvida pelo governo. Isso permitiria a elas uma melhoria na qualidade de vida com um incremento na renda, através do dinheiro que sobraria do aluguel.

O governo local sempre foi o maior latifundiário na região do DF, porém não utilizou essa sua prerrogativa de detentor de terras para providenciar moradia para as famílias que não podiam comprá-las. Esteve sempre preocupado em auferir altos ganhos com a venda dos terrenos a grandes grupos construtores da cidade, que passariam a construir prédios de luxos em áreas nobres da capital.

As politicas de habitação mostraram se ineficientes na gestão adequada do território, não possibilitando o acesso a moradia aos de menor renda, e muitas vezes sendo conivente com ocupações irregulares, ligada a todas as faixas de renda, deixando assim instaurar-se uma verdadeira crise no processo de ocupação urbana da cidade.

As famílias de baixa renda que constituíram o setor habitacional Sol Nascente, ocupando de forma irregular áreas públicas, de preservação ou não, e algumas particulares, acreditaram que essa seria a forma mais rápida de acesso a moradia, já que muitas delas vivem a anos no DF sem serem atendidas e outras foram obrigadas a se instalarem na região do entorno, por ainda não possuírem uma residência própria.

Elas enfrentaram grandes dificuldades por não possuírem infraestrutura mínima adequada no local quando se instalaram, mas sempre mantiveram-se 
com a esperança de melhora por estarem dentro de uma casa que lhes pertenceria.

A maneira como adquiriram o lote pode até certo ponto ser questionada, o que não pode ser questionado em momento algum é o direito que as famílias tem a uma casa adequada e a obrigação do governo de prover essa moradia.

O Núcleo já se encontra instalado de fato, porém ainda necessita de amplas ações governamentais de forma a garantir a melhora na qualidade de vida das pessoas que lá habitam.

O Governo não atendeu a demanda da população que lá se instalou providenciando moradia que tanto necessitavam, e agora reluta em atender as necessidades do local, implantando, quando o faz, a passos lentos equipamentos públicos para atender a comunidade.

As dificuldades que os moradores do setor enfrentam devem ser abrandadas e isso poderá ocorrer de forma mais rápida se o local passar realmente pelo devido processo de regularização. Dessa forma os governantes não poderão se furtar do dever de suprir os anseios da comunidade utilizandose do discurso que não podem fazer investimentos na área sem todo o processo ser resolvido.

A comunidade local deixa claro nas entrevistas a crença que tem de verem o setor regularizado de fato, vendo neste ato a possível solução das mazelas que atingem seus lares e suas vidas.

O papel que os governantes deveriam ter desempenhado durante 0 processo de gestão do território, ofertar moradia as famílias de baixa renda, não foi efetivado da melhor forma possível, passando a ser suprimido em parte por ações de particulares que visavam ganhos econômicos.

Núcleos urbanos sem a devida estrutura se instalaram por toda Brasília, sem possibilidade de remoção, sendo o Sol nascente uma dos exemplos mais emblemáticos devido sua enorme população. As ações governamentais voltadas para o setor devem buscar solucionar ou amenizar os problemas que lá existem ou surgem .

O comprometimento governamental deve ser no sentido de assumir a responsabilidade que tem com as famílias de baixa renda moradoras do núcleo, não permitindo que elas assumam sozinhas a responsabilidade de providenciar melhorias na localidade, pois, o motivo principal das famílias 
estarem lá é a pouca renda que possuem, portanto não cabe a elas assumirem mais essa conta. 


\section{REFERÊNCIAS BIBLIOGRÁFICAS}

AMBROGl, Sarah dias Martinez. A formação sócio espacial na compreensão da questão habitacional: Jardim João Turquino - LondrinaPR. Disponível em: <http://www.uel.br/eventos/sepech/arqtxt/resumosanais/SarahDMAmbrogi.pdf> Acesso em: 26 jun. 2010.

ARAÚJO, Saulo. Cooperativas sob investigação. Correio Braziliense. Brasília. 14 de ago. 2010. Caderno Cidades. p 34

BRANDIM, Cecília. Terras sem dono. Correio Braziliense. Brasília. 17 de fev. 2006. Caderno Cidades. p.27.

BRASIL. Constituição (1988). Constituição da República Federativa do Brasil: promulgada em 5 de outubro de 1988. Titulo II. Capítulo II. Art. 6. 29. ed. Brasília: Câmara dos Deputados, 2008. 88p.

CAMPOS, Neio. A segregação planejada. In: PAVIANNI, A. (Org.). A Conquista da cidade: movimentos populares em Brasília. Brasília. Editora UnB. 1991. p.97-113.

CARVALHO, Alberto Rodrigues Câmara de. Migrantes em Brasília: Os motivos, as dores e os sonhos numa perspectiva clínica. 192f. Dissertação de Mestrado. Universidade de Brasília-UnB. Brasília. 2008.

DOYLE, Patrícia Colela. Comercialização de habitações populares em Brasília. In: PAVIANNI, A. (Org.). Brasília: Moradia e Exclusão. Brasília. Editora UnB. 1996. p.115-137.

FARIAS, Francisco Pereira de. Clientelismo e democracia capitalista: elementos para uma abordagem alternativa. Revista de Sociologia e Política №15. Curitiba. 2000. p.49 65.Disponívellemm:<http://www.scielo.br/pdf/rsocp/ n15/a04n15.pdf> Acesso em: 07 ago. 2010.

FERREIRA, Ignez Costa Barbosa. Gestão do território e novas territorialidades. In: PAVIANNI, A. (Org.). Brasília - gestão urbana: conflitos e cidadania. Brasília: Editora UnB. 1999. p.135-143. 
GANEM, Roseli Senna, et al. Ordenamento territorial e plano diretor: o caso do Distrito Federal. Cadernos ASLEGIS 34. maio/agosto. Brasília. 2008. Disponível em: <http://www.aslegis.org.br/aslegis/images/cadernos/Caderno s34/05\%20revista34_ordenamento\%20territorial\%20p\%2079-98.pdf > Acesso em: 28 jun. 2010.

GOUVÊA, Luiz Alberto. A capital do controle e da segregação social. In: PAVIANNI, A. (Org.). A conquista da cidade: movimentos populares em Brasília. Brasília. Editora UnB. 1991. p.75-96.

Habitação e emprego: Uma política habitacional de interesse social. In: PAVIANNI, A. (Org.). Brasília Moradia e Exclusão. Brasília. Editora UnB. 1996. p. 231-250.

GOVERNO DO DISTRITO FEDERAL. O Distrito Federal - Síntese de Informações Socioeconômicas 2008. Brasília : CODEPLAN, 2008. 89 p. Disponível em: <http://www.codeplan.df.gov.br/sites/200/216/00000327.pdf> Acesso em: 12 jun. 2010.

Pesquisa distrital por amostra de domicílios - 2004: dados agregados para o Distrito Federal e Regiões administrativas. Brasília: SEPLAN. 162p. Disponível em:<http://www.distritofederal.df.gov.br/sites/100/14 6/download/PDAD_2004.pdf> Acesso em: 12 jun. 2010.

Indicadores sociodemográficos prospectivo para o Distrito Federal 1991-2030. Brasília. CODEPLAN, 2009. 88p. Disponível em: < http://www.codeplan.df.gov.br/sites/200/216/00000335.pdf> Acesso em: 14 jun. 2010.

Indicadores de desigualdade social no Distrito Federal. Brasília. CODEPLAN: NEP, 2007. 44p. Disponível em: <http://www.codeplan.df. gov.br/sites/200/216/00000192.pdf> Acesso em: 14 de jun. 2010.

GUIA, George Alex da. Políticas territorias, segregação e reprodução das desigualdades sócios-espaciais no aglomerado urbano de Brasília. $198 \mathrm{f}$. Dissertação (Mestrado em Arquitetura e Urbanismo). Faculdade de Arquitetura. Universidade de Brasília-UnB. Brasília. 2006.

JUNIOR, Luiz de Pinedo Quinto; IWAKAMI, Luiza Naomi. O canteiro de obras da cidade planejada e o fator de aglomeração. In: PAVIANNI, A. (Org.). A conquista da Cidade: movimentos populares em Brasília. Brasília. Editora UnB. 1991. p. 55-73. 
LUIZ, Edson Beú. Os filhos dos candangos: exclusão e identidades. $140 f$. Dissertação (Mestrado em História). Instituto de ciências humanas. Departamento de História. Universidade de Brasília-Unb. Brasília. 2007.

MALAGUTTI, Cecília J. Loteamentos clandestinos no Distrito Federal: caminhos alternativos para a sua aceitação. In: PAVIANNI, A. (Org.) Brasília gestão urbana: conflitos e cidadania. Brasília. Editora UnB. 1999. p.55-84.

MINISTÉRIO DAS CIDADES. Déficit habitacional no Brasil 2007. Secretaria Nacional de Habitação. Brasília, 2009. p.129. Disponível em: <http://www.cidad es.gov.br/secretarias-nacionais/secretaria-de habitacao/biblioteca/publicacoese-artigos/DeficitHabitacional.zip/view> Acesso em: 14 de jun. 2010.

OLIVEIRA, Juscelino Kubitschek. Assim nasceu Brasília. Disponível em: <http://web.brasiliapoetica.blog.br> Acessado em 03/07/2010.

A Visão de Juscelino Kubitschek. Disponível em: <http://www.gdf.df.gov.br/045/04501021.asp> Acesso em: 03 ago. 2010

OLIVEIRA, Tony Marcelo Gomes de. Marcas do processo de formação do espaço urbano de Brasília pela ótica da erradicação de favelas. Univ. Hum., Brasília, v. 5, n. 1/2, p. 49-76, jan./dez. 2008. Disponível em: < http://www.publicacoesacademicas.uniceub.br/index.php/universitashumanas/a rticle/viewFile/876/610 > Acesso em: 18 jun. 2010.

PACELLI, Marcio. Nove anos vivendo ao Pôr do Sol. Correio Braziliense.Brasília. 30 de ago. 2009. Caderno Cidades, p.42.

PAVIANNI, Aldo. Migrações com desemprego: injustiça social na configuração sócioespacial urbana. In: Cadernos Metrópole 17. Instituto nacional de ciência e tecnologia. 2007. p. 13-33. Disponível em: $<$ http://web.observatoriodasmetropoles.net/index.php?option=com_content\&vie $\mathrm{w}=$ article\&id=664\&ltemid=84\&qual=3\&info=4> Acesso em: 24 jun. 2010.

A construção injusta do espaço urbano. In: PAVIANNI, A. (org). A conquista da Cidade: movimentos populares em Brasília. Brasília. Editora UnB. 1991. p.115-142.

Migrações e essencialidades urbanas. Correio Braziliense. Brasília. 14 de fev. 2008. Caderno Dois. Opinião. p.23. 
PELUSO, Marília L. Brasília: do mito ao plano, da cidade sonhada à cidade administrativa. Espaço e Geografia, Vol.6, No 2. Brasília. 2003. Universidade de Brasília-UnB. p.1-29.

Loteamentos irregulares e meio ambiente no Distrito Federal: espaço, tempo e memória na apropriação do território. Cadernos do CEAM (UnB), Brasília. 2009.

PENNA, Nelba de Azevedo. Fragmentação do ambiente urbano: crises e contradições. In: PAVIANNI, A; GOUVEÂ, L. A. (Orgs.) de C. Brasília; controvérsias ambientais. Brasília. 2003. Editora UnB. p.57-73.

. Urbanização cidade e meio ambiente. GEOUSP - Espaço e tempo. № 12. São Paulo. 2002. Não paginado. Disponível em: < http://www.geografia.fflch.usp.br/publicacoes/Geousp/Geousp12/Geousp12_Ne IbaPenna.htm> Acesso em: 14 de mar. 2010.

RIBEIRO, Gustavo Lins. O capital da esperança: a experiência dos trabalhadores na construção de Brasília. Brasília. Editora UnB. 2008.

Acampamento de grande projeto: uma forma de imobilização da força de trabalho pela moradia. In: PAVIANNI, A. (Org.). A conquista da Cidade: movimentos populares em Brasília. Brasília. Editora UnB. 1991. p. 2553.

STUMPF, Ricardo; SANTOS, Zilda M. Habitação: novos enfoques e perspectivas. In: PAVIANNI, A. (Org.). Brasília: moradia e exclusão. Brasília. Editora UnB. 1996. p.27-52.

SILVEIRA, Denise Prudente de F. Gestão territorial do Distrito Federal. In: PAVIANNI, A. (Org.). Brasília - gestão urbana: conflito e cidadania. Brasília. Editora UnB 1999. p.145-166.

VASCONCELOS, Ana Maria Nogales, et al. Da utopia à realidade: uma análise dos fluxos migratórios para o Aglomerado Urbano de Brasília. In: XV Encontro Nacional de Estudos Populacionais.Caxambu- MG. ABEP. 2006. Disponível em: <http://www.abep.nepo.unicamp.br/encontro2006/docspdf/ABE P2006_299.pdf > Acesso em: 07 jun. 2010. 
TAHAN, L; MADER, H; AZEDO, L.C. O caos da explosão demográfica. Correio Braziliense. Brasília. 12 de out. 2008. Caderno Cidades. p.40. 
ANEXOS 


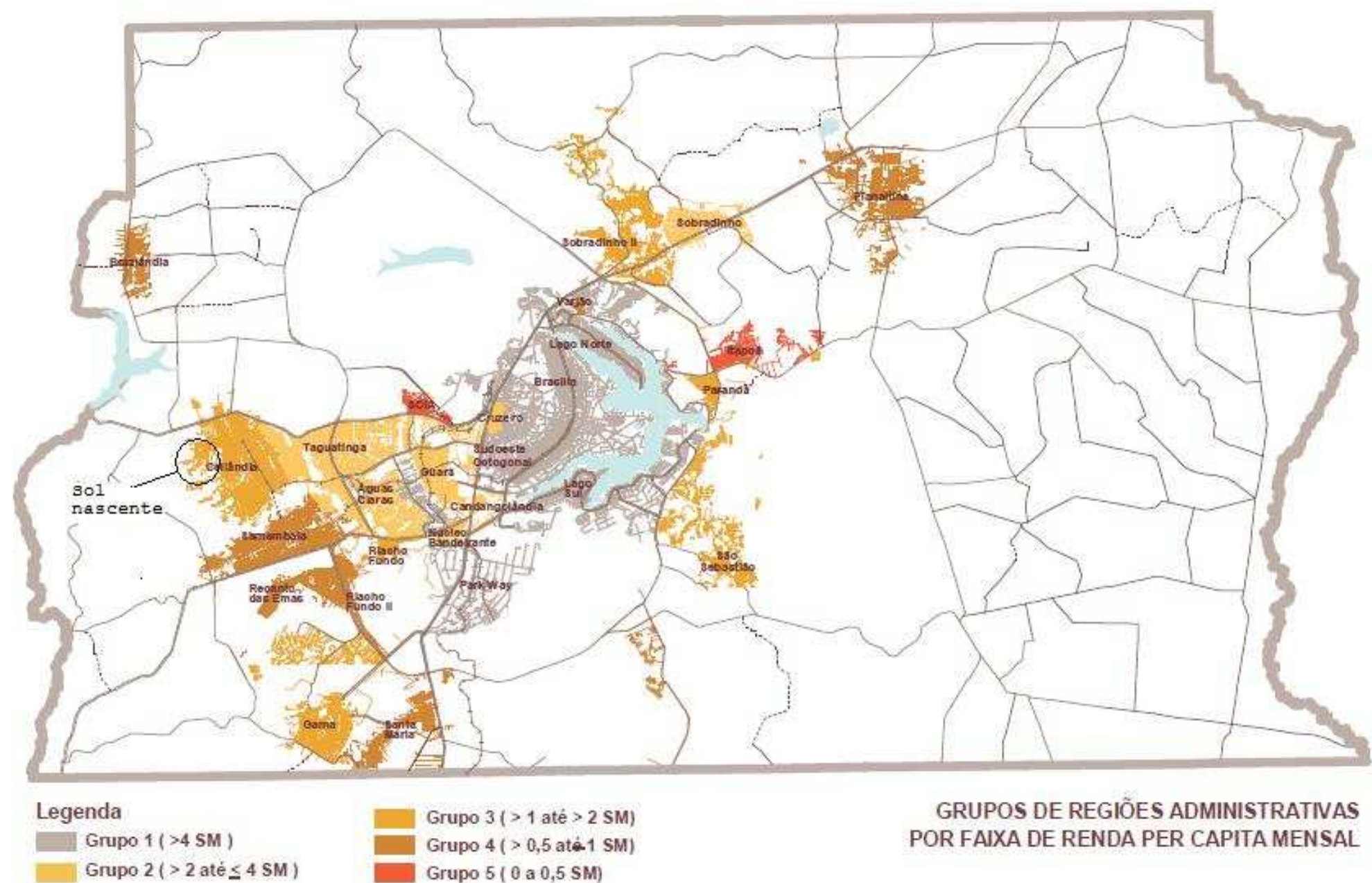

Fonte: PDAD-2004/ Indicadores de Desigualdade Social no Distrito Federal / Companhia de Planejamento do Distrito Federal. - Brasília, DF : CODEPLAN : NEP, 2007. 
Figura 1

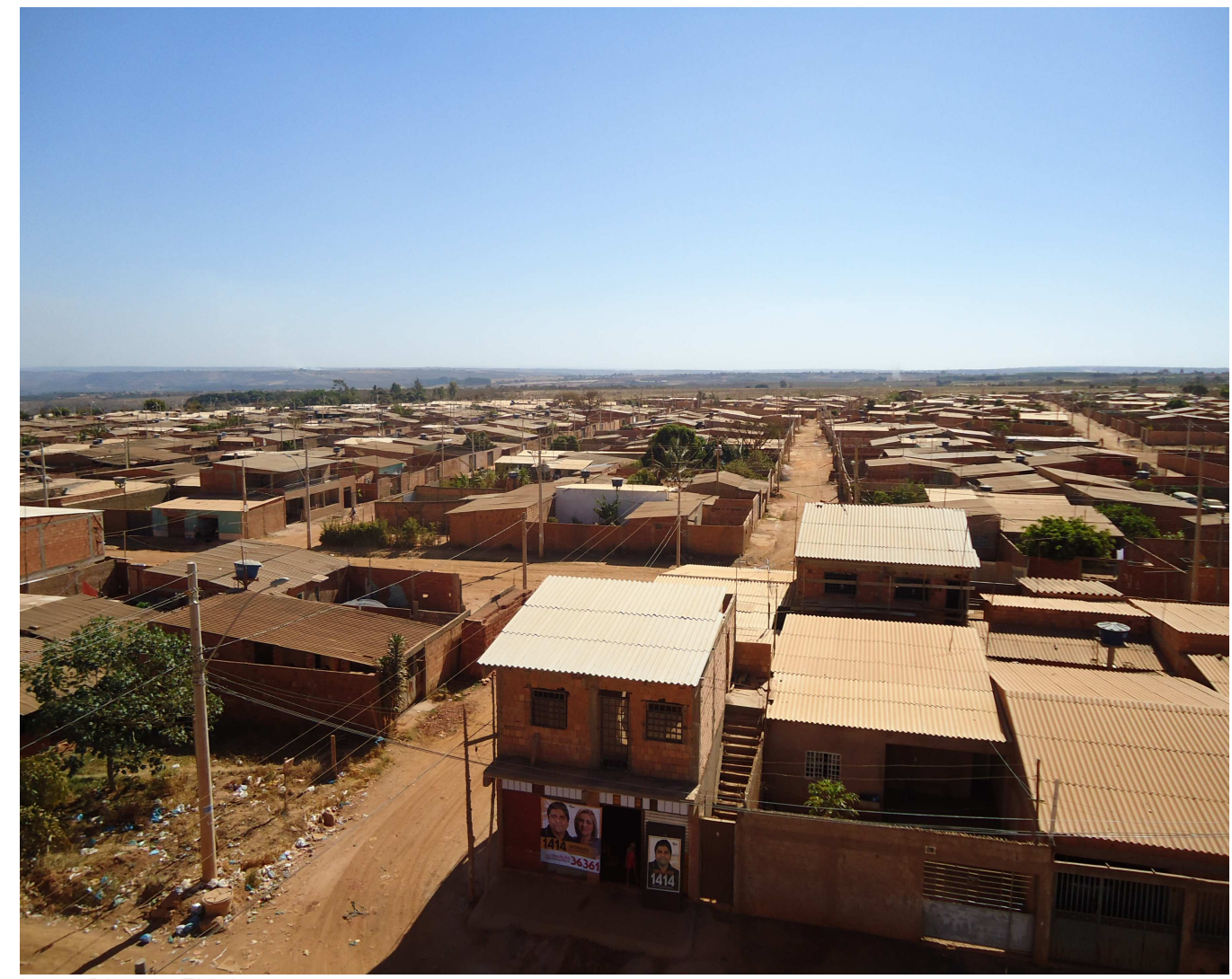

Autor: Ricardo Fideles

Vista aérea do Núcleo

Figura 2

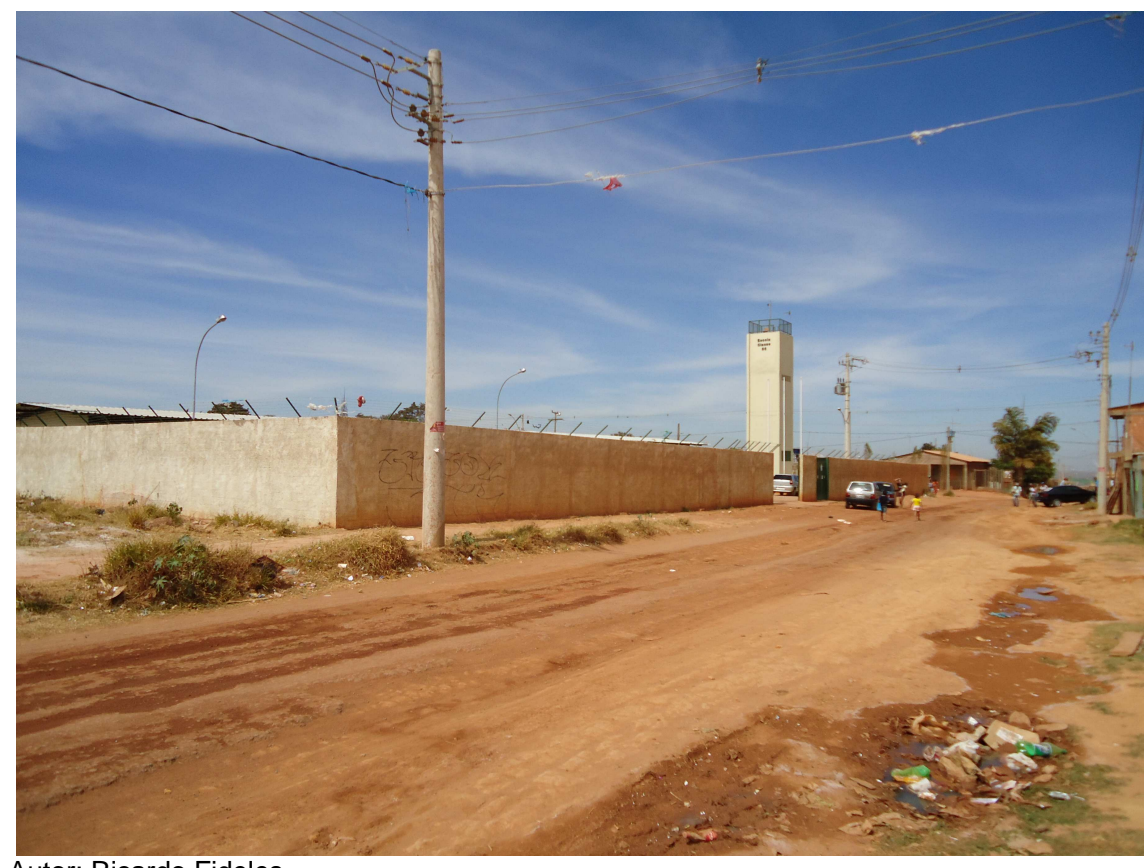

Autor: Ricardo Fideles

Frente do Centro de Ensino Fundamental 66 
Figura 3

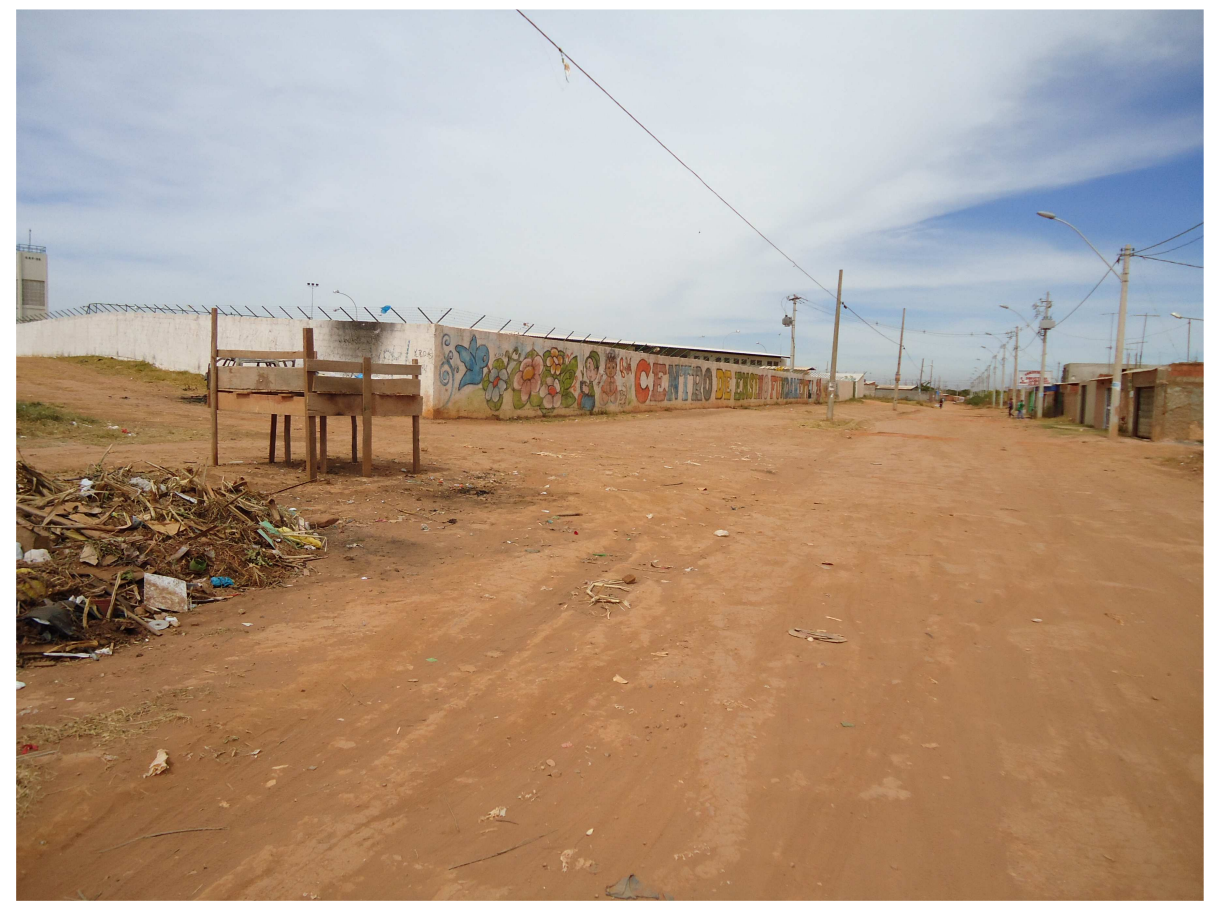

Autor: Ricardo Fideles

Frente do Centro de Ensino Fundamental 28

Ruas de frente as escolas, sem sistema de captação de águas pluviais, rede de esgoto, asfaltamento e com coleta precária de lixo.

\section{Figura 4}

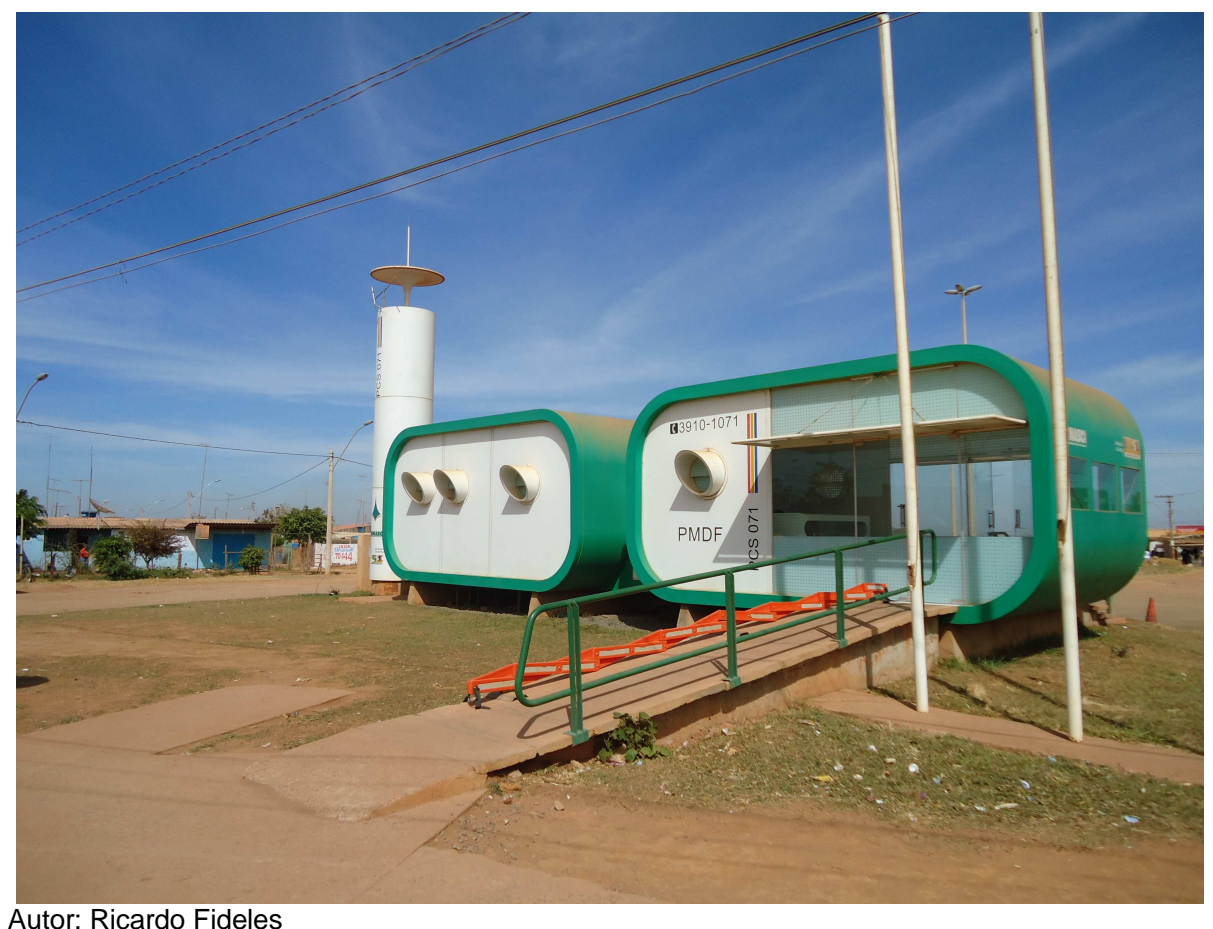

Posto da polícia militar na entrada da avenida principal 
Figura 5

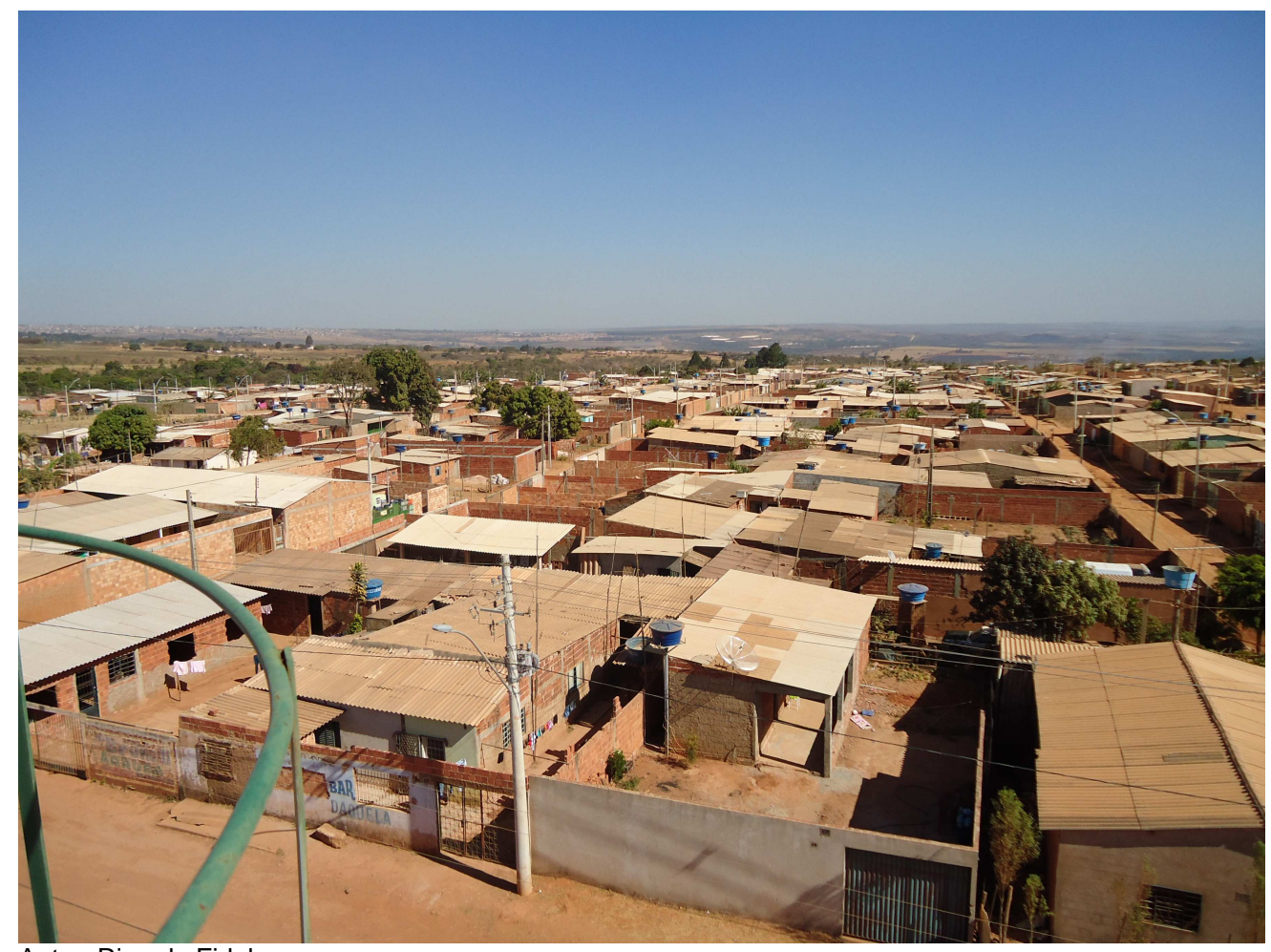

Autor: Ricardo Fideles

Visão aérea do Setor que permite verificar a instalação das caixas d'água, agora com fornecimento da Caesb.

Figura 6

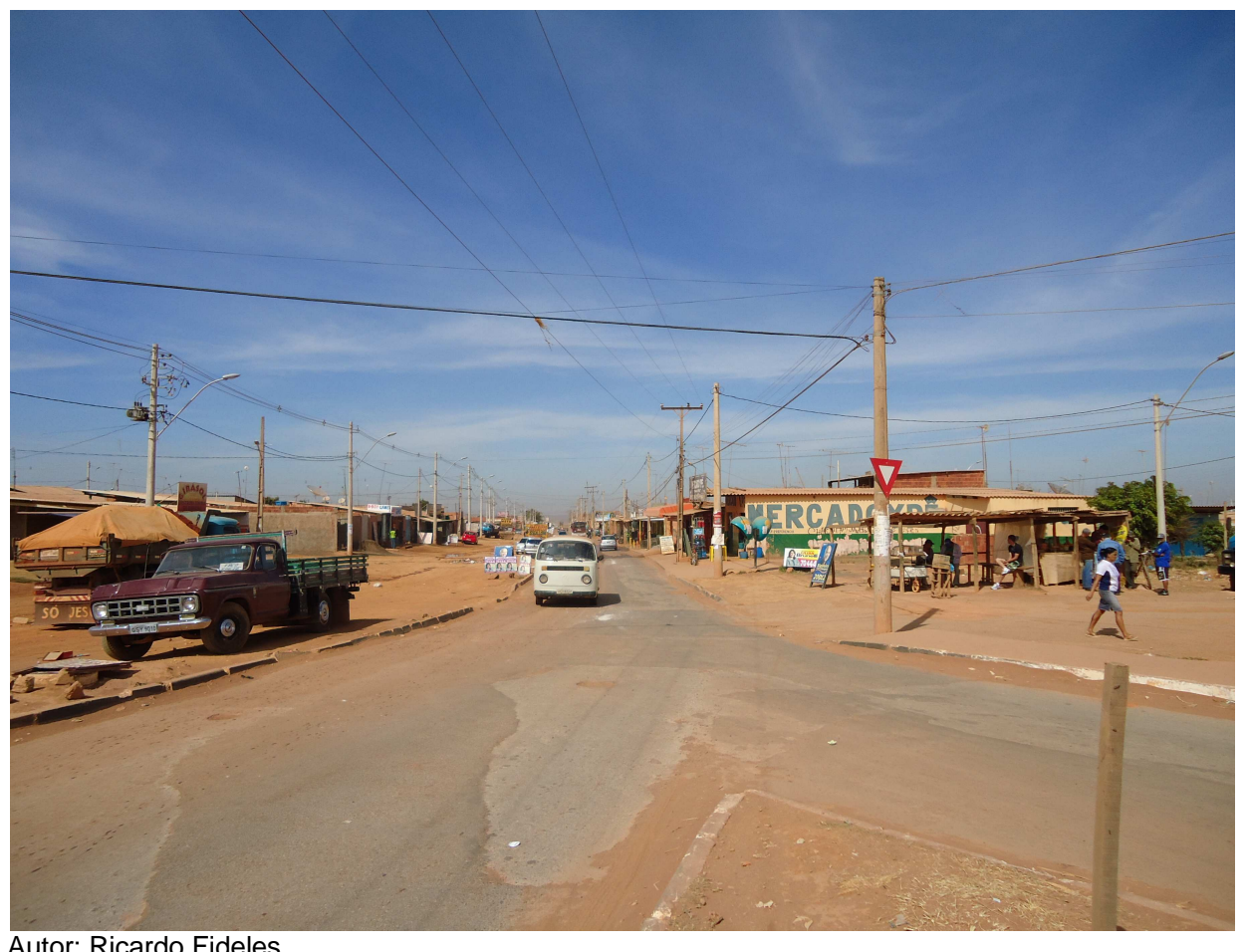


Figura 7

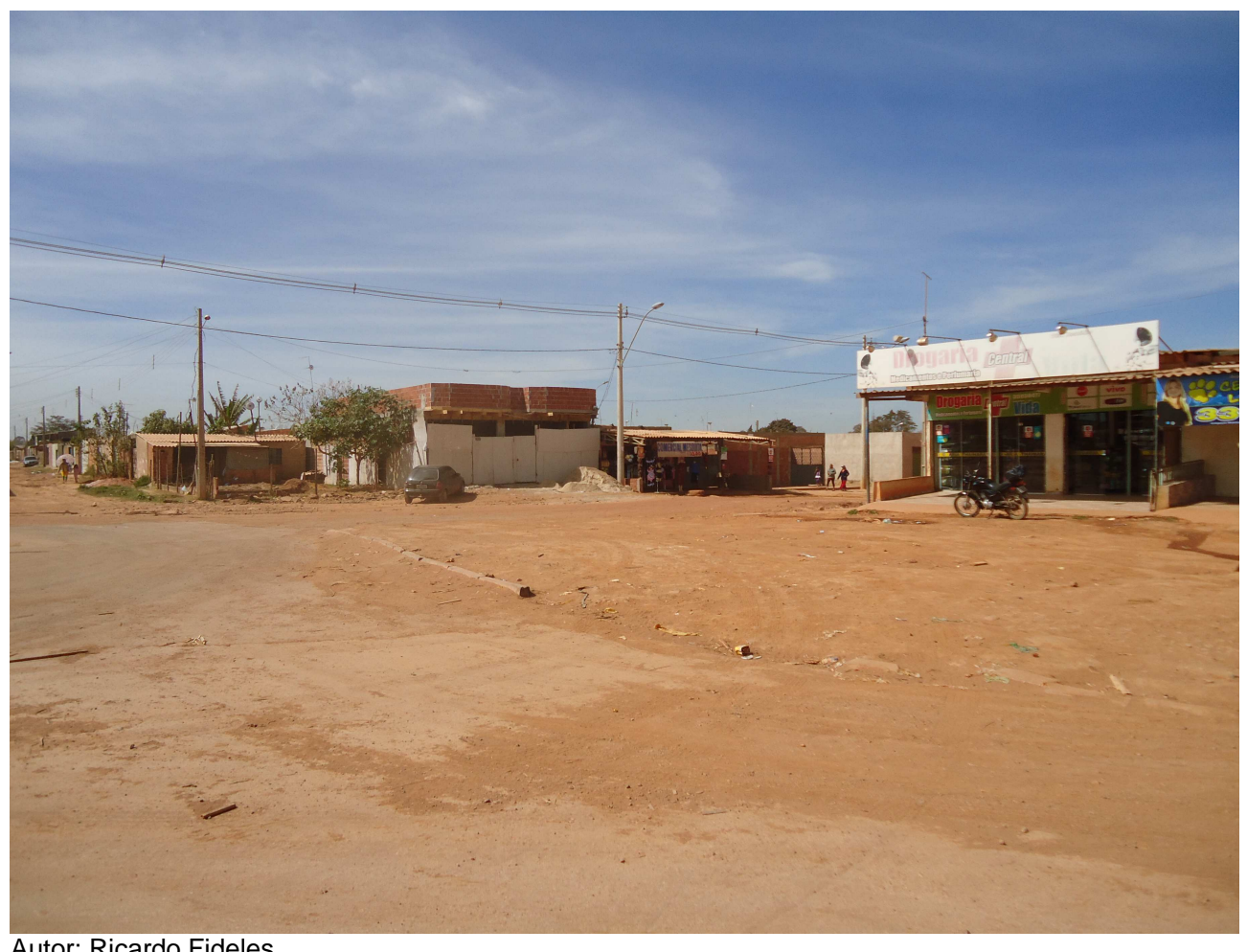

Final da avenida principal, um dos pontos que mais apresentam problemas na época de chuvas por ser uma conjunção de várias ruas.

Figura 8

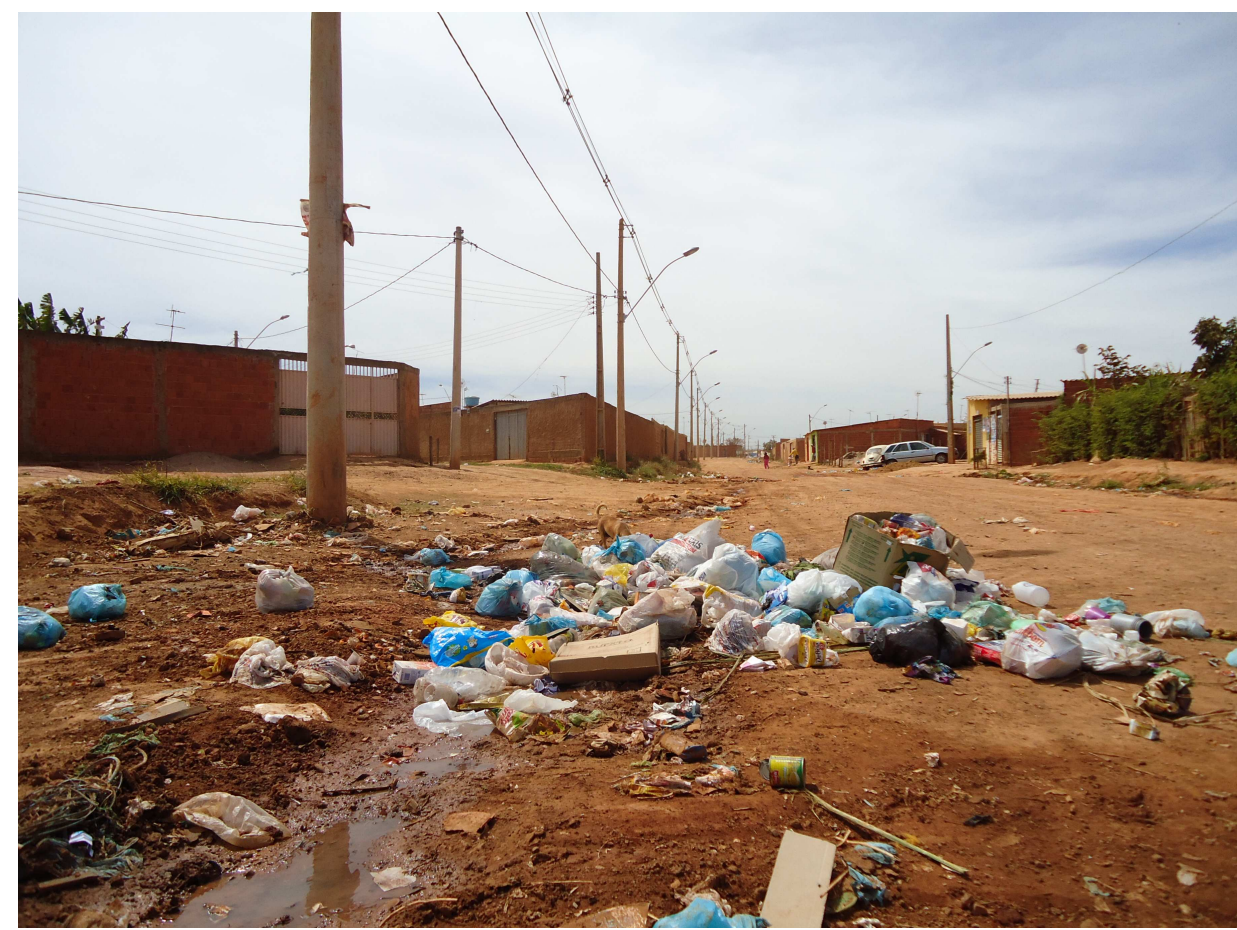

Autor: Ricardo Fideles

Imagem de rua que não havia sido feita a coleta do lixo 
Figura 9

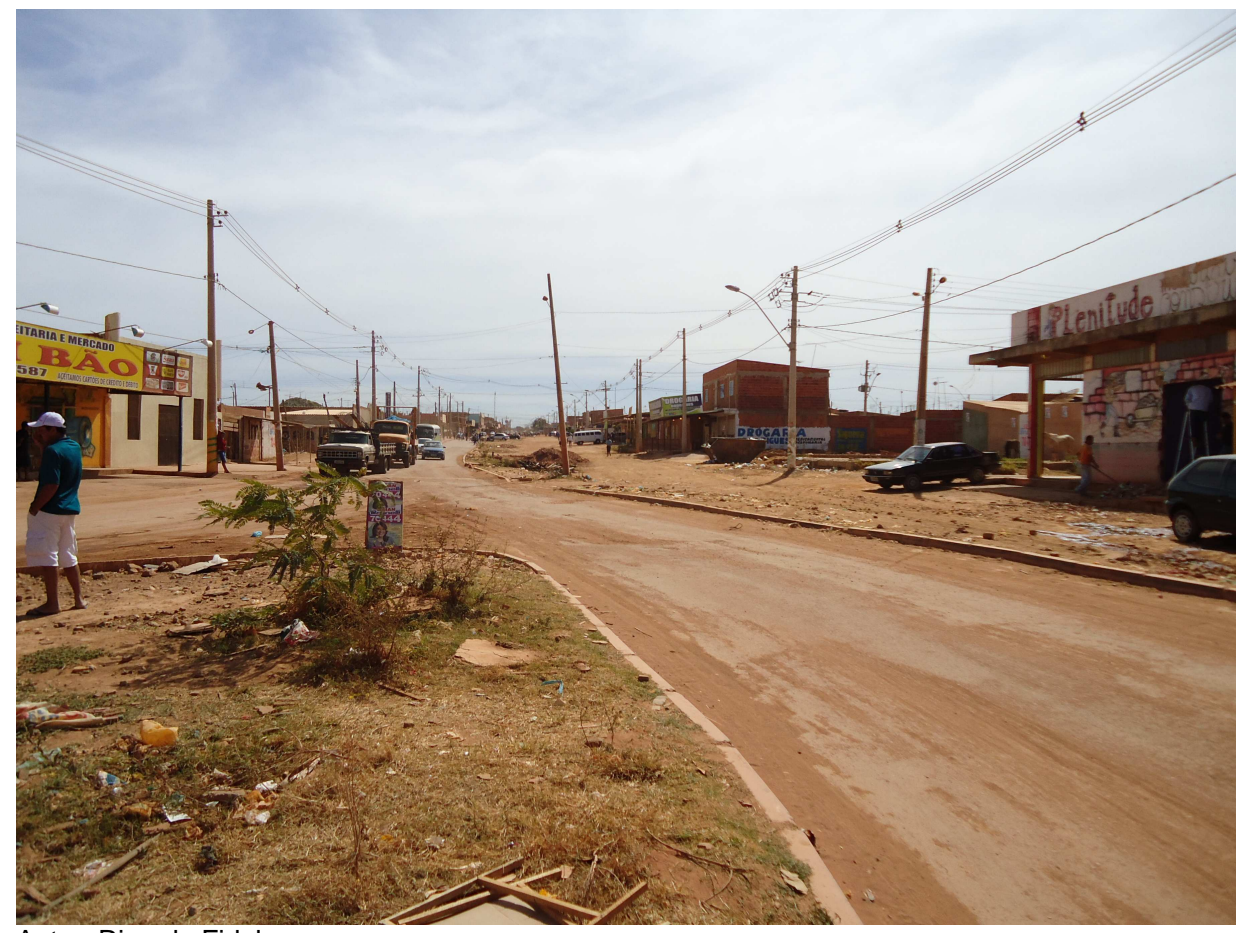

Autor: Ricardo Fideles

Imagem do que resta de asfalto da única via pavimentada

Figura 10

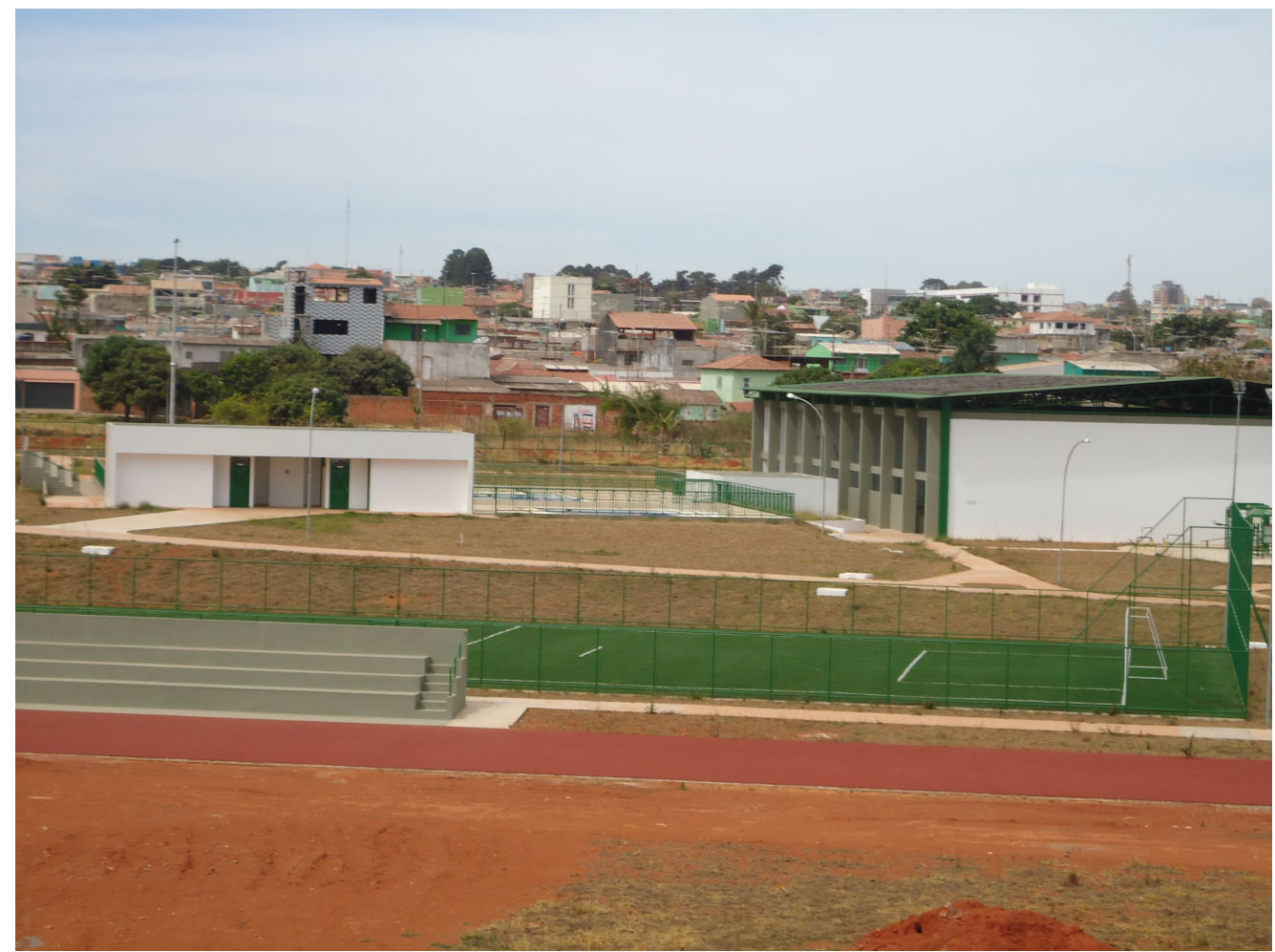

Autor: Ricardo Fideles

Imagem da obra - agora parada - da futura vila olímpica 
Figura 11

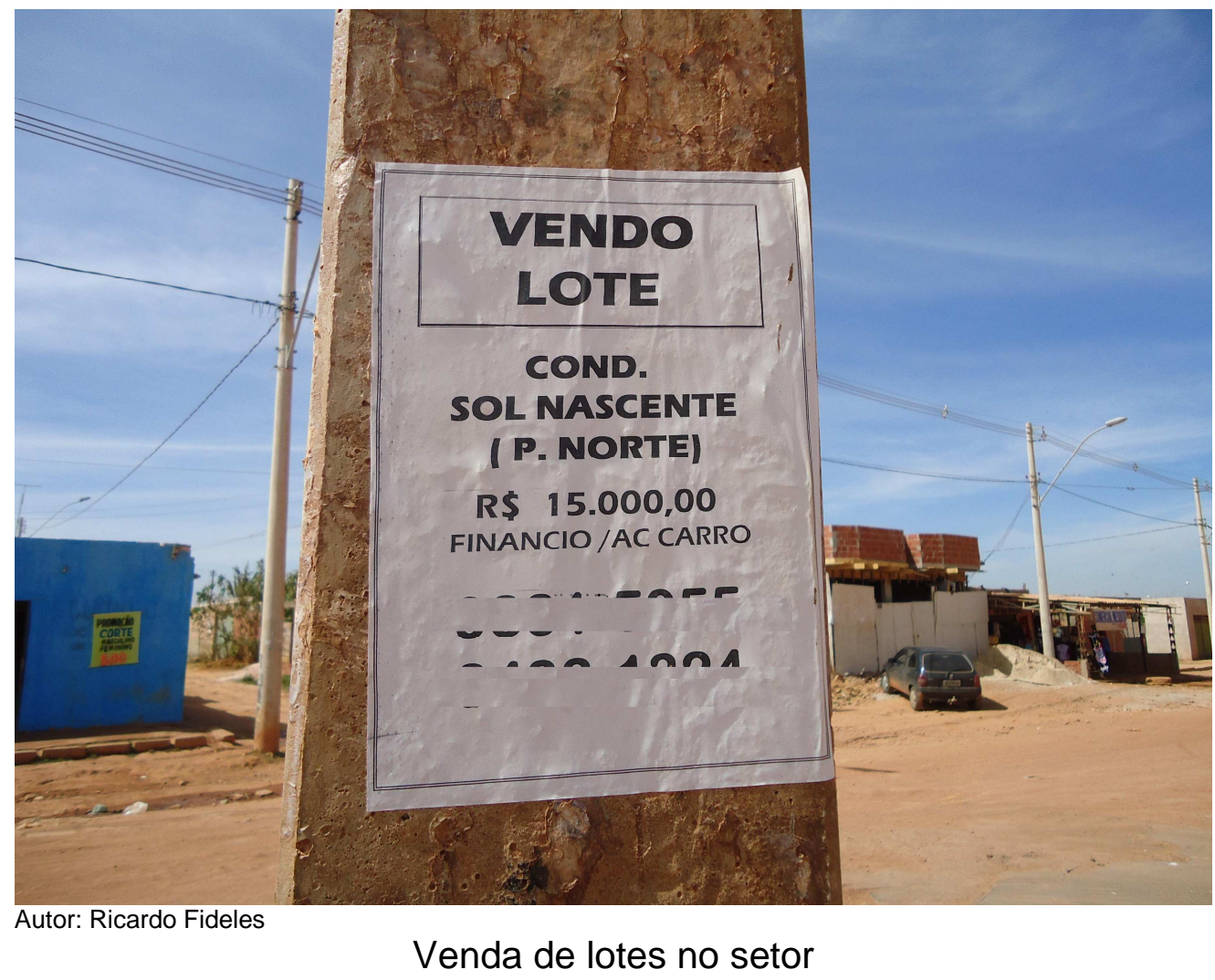


Figura 12

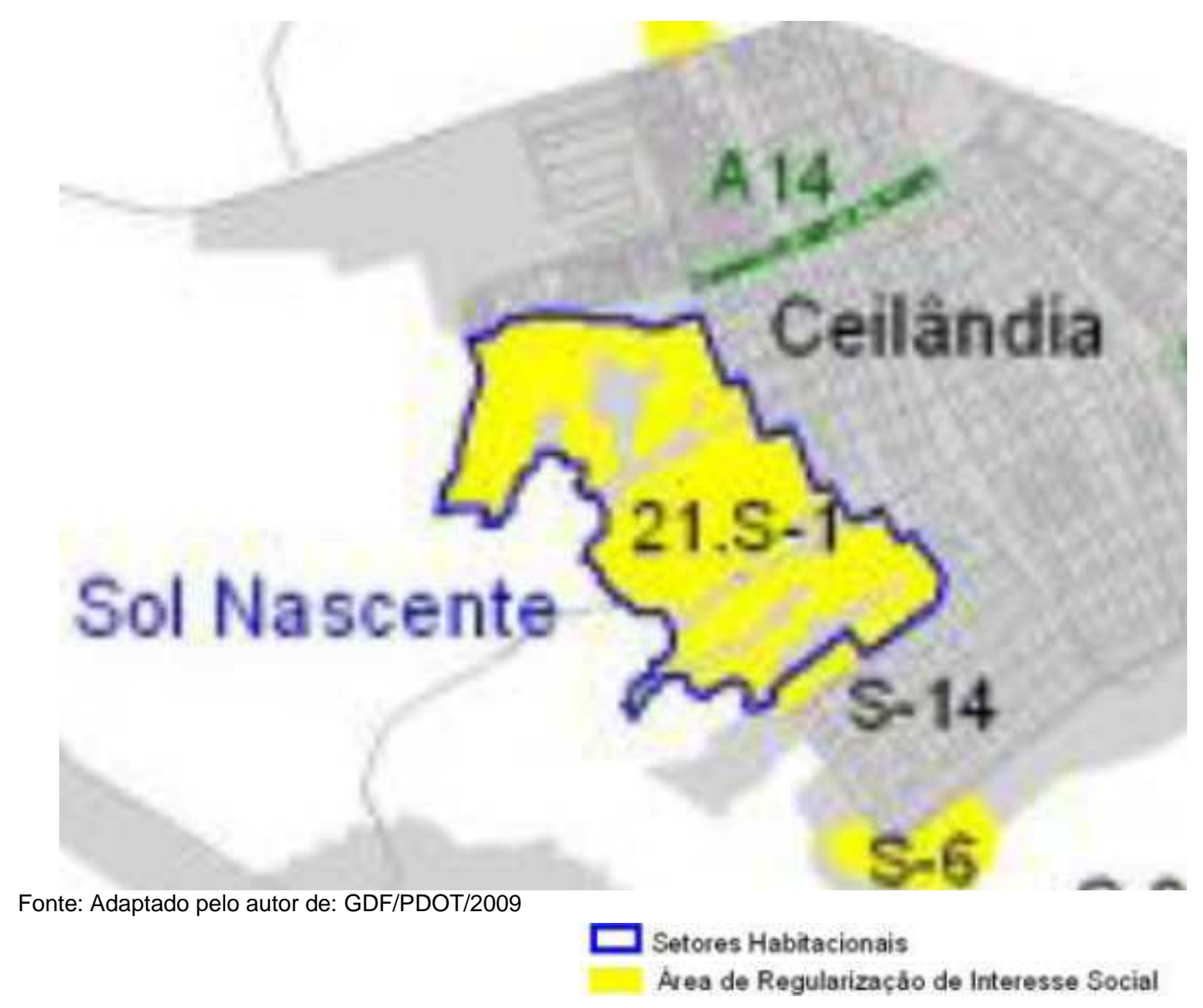

Representação parcial do mapa de estratégias de regularização Fundiária e de oferta de áreas habitacionais 


\section{ROTEIRO DA ENTREVISTA}

1- NOME ( NÃO É NECESSÁRIO SOBRENOME): IDADE:

2- ESTADO ONDE NASCEU, SE NÃO FOR DE BRASÍLIA:

3- HÁ QUANTO TEMPO MORA EM BRASÍLIA?

4- POR QUE MUDOU PARA BRASÍLIA?

7- CASADO? SOLTEIRO? VIVE COM COMPANHEIRO(A)?

8- POSSUI FILHOS(AS)? QUANTOS:

5- VOCÊ ESTÁ INSCRITO NO PROGRAMA HABITACIONAL DO DF? SE NÃO POR QUAL MOTIVO?

6- QUAL A RENDA FAMILIAR MENSAL EM SALÁRIOS MÍNIMOS?

9- HÁ QUANTO TEMPO MORA NO SOL NASCENTE?

10- QUANTAS PESSOAS MORAM NA CASA COM VOCÊ?

11- EM QUE CIDADE DE BRASÍLIA OU ENTORNO MORAVA ANTES DE MUDAR PARA O SOL NASCENTE?

12- PAGAVA ALUGUEL OU MORAVA COM PARENTES? SE PAGAVA ALUGUEL QUAL ERA O VALOR GASTO?

13- COMO FICOU SABENDO DA VENDA DE LOTES NO SOL NASCENTE?

14- VOCÊ SABIA QUE A ÁREA ONDE ESTAR O SHSN ERA DO GOVERNO QUANDO COMPROU O LOTE?

15- A CASA EM QUE VOCÊ MORA AQUI NO SHSN É SUA OU DE UM PARENTE? NO DE SER SUA COMO VOCÊ A COMPROU?

16- QUAL O MAIOR PROBLEMA DO SETOR PRA VOCÊ?

17- VOCÊ ACHA QUE OS GOVERNOS DO DF, QUE VOCÊ JÁ CONHECEU, ESTÃO PREOCUPADO EM OFERECER MORADIA PARA FAMÍLIAS DE BAIXA RENDA?

18- VOCÊ CONCORDA QUANDO DIVULGAM QUE OS MORADORES DO SHSN SÃO INVASORES POR ESTAREM EM TERRAS DO GOVERNO SEM QUE ELE TENHA AUTORIZADO? 